\title{
Pulmonary Hypertension Remodels the Genomic Fabrics of Major Functional Pathways
}

\author{
Rajamma Mathew ${ }^{1,2}$, Jing Huang ${ }^{1}$, Sanda Iacobas ${ }^{3}$ and Dumitru A. Iacobas ${ }^{4, *(1)}$ \\ 1 Department of Pediatrics, New York Medical College, Valhalla, NY 10595, USA; rmathew@nymc.edu (R.M.); \\ jinghuang100@gmail.com (J.H.) \\ 2 Department of Physiology, New York Medical College, Valhalla, NY 10595, USA \\ 3 Department of Pathology, New York Medical College, Valhalla, NY 10595, USA; sandaiacobas@gmail.com \\ 4 Personalized Genomics Laboratory, Center for Computational Systems Biology, Roy G Perry College of \\ Engineering, Prairie View A\&M University, Prairie View, TX 77446, USA \\ * Correspondence: daiacobas@pvamu.edu; Tel.: +1-936-261-9926
}

Received: 17 December 2019; Accepted: 21 January 2020; Published: 23 January 2020

check for updates

\begin{abstract}
Pulmonary hypertension $(\mathrm{PH})$ is a serious disorder with high morbidity and mortality rate. We analyzed the right-ventricular systolic pressure (RVSP), right-ventricular hypertrophy (RVH), lung histology, and transcriptomes of six-week-old male rats with PH induced by (1) hypoxia (HO), (2) administration of monocrotaline (CM), or (3) administration of monocrotaline and exposure to hypoxia (HM). The results in PH rats were compared to those in control rats (CO). After four weeks exposure, increased RVSP and RVH, pulmonary arterial wall thickening, and alteration of the lung transcriptome were observed in all $\mathrm{PH}$ groups. The HM group exhibited the largest alterations, as well as neointimal lesions and obliteration of the lumen in small arteries. We found that $\mathrm{PH}$ increased the expression of caveolin1, matrix metallopeptidase 2, and numerous inflammatory and cell proliferation genes. The cell cycle, vascular smooth muscle contraction, and oxidative phosphorylation pathways, as well as their interplay, were largely perturbed. Our results also suggest that the upregulated Rhoa (Ras homolog family member A) mediates its action through expression coordination with several ATPases. The upregulation of antioxidant genes and the extensive mitochondrial damage observed, especially in the HM group, indicate metabolic shift toward aerobic glycolysis.
\end{abstract}

Keywords: aerobic glycolysis; caveolin1; hypoxia; monocrotaline; oxidative phosphorylation; RhoA

\section{Introduction}

Pulmonary hypertension $(\mathrm{PH})$, characterized by increasing pulmonary artery pressure and vascular resistance [1], is a serious complication of a number of unrelated cardiopulmonary, inflammatory, and autoimmune diseases, as well as of drug toxicity. PH is characterized by endothelial dysfunction, enhanced vasoconstrictor reactivity, activation of proliferative and anti-apoptotic pathways, vascular remodeling, elevated pulmonary artery pressure, and right-ventricular hypertrophy (RVH), leading to right-ventricular failure and premature death.

Recently updated PH classification maintains the original five groups with some modification [2]. The term pulmonary arterial hypertension (PAH) is assigned to Group1. It includes idiopathic (IPAH) and heritable PAH (HPAH), PAH associated with congenital heart diseases, drug toxicity, connective tissue disorders, portal hypertension, human immunodeficiency virus (HIV) infection, and schistosomiasis. The average survival time in patients with PAH without treatment was reported in 1991 to be around 2.8 years [3]. Despite the improvement in quality of life, the current therapy fails to reverse or halt the progression of the vascular disease [4]. Progressive pulmonary vascular changes lead to neointimal lesions resulting in irreversibility of the PH [5]. The five-year survival rate remains 
poor in patients with IPAH, HPAH, and PAH associated with anorexigenic drug treatment [6,7]. PAH diagnosis is often delayed because of the vague symptoms. By the time the diagnosis is made, most of the patients have significant pathological changes in the pulmonary vasculature, which poses a serious challenge to therapeutic measures.

Mutations of genes BMPR2 (bone morphogenetic protein receptor type 2) [8], ACVRL1 (activin A receptor like type 1) [9], ENG (endoglin) [10], SMAD9 (SMAD family member 9) [11], CAV1 (caveolin 1) [12], and KCNK3 (potassium two-pore domain channel subfamily K member 3) [13] are well-documented causes of PAH.

About $20 \%$ of people with BMPR2 mutation develop $\mathrm{PH}$, indicating that a second hit is necessary, which could be mutations in additional transcription factors such as EIF2AK4 [14] or SMAD9 [15]. Importantly, patients with mutation and PAH tend to be younger [16]. In addition, $42 \%$ females who harbor BMPR2 mutation develop PAH compared with 14\% males. This difference is attributed to the protective effect of Y-chromosome specific transcription factor SRY (sex-determined transcription region Y), which positively regulates BMPR2 [17].

Monocrotaline (MCT)- and hypoxia-induced PH are well-established animal models. MCT is a pyrrolizidine compound obtained from seeds and leaves of Crotalaria spectabilis. Following a single sc injection, MCT is converted in the liver to dehydroMCT, which, during the first passage through the lungs, causes pulmonary endothelial damage. By $72 \mathrm{~h}$, the compound is completely excreted. Within one week, endothelial disruption and loss of endothelial membrane proteins such as Cav1, PECAM, and Tie2 occur. By two weeks post MCT, PH is observed [18].

Loss of Bmpr2 was observed in the MCT and hypoxia models of PH [19]. BMPR2 gene therapy fails to inhibit MCT-induced PH; however, administration of GDF2 (growth differentiation factor 2, also known as BMP9) was shown to have preventive and reversal effect on experimental PH [20,21]. $B M P R 2$ is predominantly expressed in endothelial cells, and a part of it co-localizes with CAV1 [22], while the loss of BMPR2 increases the susceptibility to DNA damage [23]. The increased expression of SMURF1 (SMAD-specific E3 ubiquitin protein ligase 1) that induces lysosomal and proteosomal degradation of BMPR2 was shown to occur in patients with PAH, as well as in hypoxia- and MCT-induced PH. Furthermore, Smurf1 deletion protects mice from PAH [19,24]. Robust expression of Nos3 (nitric oxide synthase 3) was reported in plexiform lesions in PAH [25].

The importance of CAV1 in PH is supported by recent observations that patients with CAV1 mutation develop PAH [12]. In addition, Cav1 knockout mice develop PH which can be reversed by reconstituting endothelial Cav1 [26,27]. Extensive loss of endothelial CAV1 accompanied by enhanced expression of CAV1 in vascular smooth muscle cells (VSMC) was reported in IPAH, in HPAH, in PAH associated with congenital heart defect and drug toxicity [22,28-31], and in infants with bronchopulmonary dysplasia and evidence of inflammation [29]. Furthermore, pulmonary artery smooth muscle cells isolated from patients with $\mathrm{PH}$ revealed enhanced expression of $C A V 1$, increased capacitative $\mathrm{Ca}^{2+}$ entry, and increased DNA synthesis, which could be blocked by CAV1 small interfering RNA (siRNA) [28]. Inflammation was shown to play a significant role in PH, and CAV1 modulates inflammatory response. Furthermore, Cav1 knockout mice have increased levels of circulating pro-inflammatory cytokines [32]. In the experimental models of $\mathrm{PH}$, loss of Cav1 was shown to be associated with increased levels and bioactivity of Il6, and activation of Stat3 and Nfkb1. Rescue of Cav1 results in the attenuation of $\mathrm{PH}[32,33]$.

We previously showed that exposing the MCT-injected rats to hypoxia accelerates the PH disease process. By four weeks, there is extensive endothelial Cav1 loss, accompanied by enhanced expression of Cav1 in VSMC of a large number of arteries, resulting in near normalization of total Cav1 protein expression in the lungs. Several of the arteries with enhanced expression of Cav1 displayed neointima formation. Moreover, lung Nos3 expression in this group was near normal levels unlike the group of MCT-injected rats exposed to normal atmosphere, where the lung Nos3 level was low. Importantly, lung sections from IPAH and HPAH patients revealed a similar sequence of events: (1) loss of endothelial CAV1 and endothelial cell disruption, (2) enhanced expression of CAV1 in VSMC, and (3) presence 
of neointima only in arteries that displayed enhanced expression of CAV1 in VSMC [30]. In vitro studies with pulmonary artery endothelial cells from IPAH patients have CAV1 degradation owing to sustained NOS3 and SRC signaling [34]. Furthermore, loss of CAV1 in endothelial cells was shown to cause mitochondrial stress, as well as increase oxidative stress and metabolic switch [35].

In this article, we present our observations on the four-week weight gain, right-ventricular systolic pressure (RVSP), right-ventricle hypertrophy (RVH), pulmonary vascular histology, and lung transcriptomes of three rat models of $\mathrm{PH}$ with respect to the control group.

\section{Materials and Methods}

\subsection{Animals}

The six-week-old male Sprague-Dawley rats (150-175g) were obtained from Charles River Wilmington, MA. Rats were allowed to acclimatize in the animal facility for five days and had free access to laboratory chow and water. The rats were kept in the animal facility maintained at $22{ }^{\circ} \mathrm{C}$ and $12 \mathrm{~h}$ each of light and dark cycle. The experiments respected the guiding principles for the use and care of laboratory animals of the American Physiological Society and the National Institutes of Health. The Institutional Animal Care and Use Committee at New York Medical College approved the protocol "Mechanism of neointima formation in pulmonary hypertension" (approval \# 4-1-0113/2014, P.I., R.M). Rats were divided into four groups ( $n=8$ /group). Gr1, control rats (CO), were maintained in room air. Gr2 (CM) rats received a single subcutaneous injection of monocrotaline (MCT $40 \mathrm{mg} / \mathrm{kg}$ ) and were kept in room air. $\mathrm{Gr} 3(\mathrm{HO})$ rats were subjected to hypobaric hypoxia (atmospheric pressure $380 \mathrm{mmHg}$, $\left.10 \% \mathrm{O}_{2}\right)$. Gr4 $(\mathrm{HM})$ rats received MCT $40 \mathrm{mg} / \mathrm{kg}$ and were subjected to hypobaric hypoxia starting on day one. The hypoxia chamber was opened twice per week for $15 \mathrm{~min}$ to weigh the rats, replenish food and water, and provide clean bedding similar to the other rats in room air. We did not notice any obvious cyanosis in these rats; however, increased hemoglobin levels were reported. At the end of four weeks, these rats were studied. All chemicals were purchased from Sigma Aldrich, St Louis, MO, USA.

\subsection{Measurement of Right-Ventricular Systolic Pressure (RVSP)}

As previously described [36], rats were anesthetized with an intraperitoneal injection of xylazine $(6 \mathrm{mg} / \mathrm{kg})$ and ketamine $(60 \mathrm{mg} / \mathrm{kg})$. Through an incision in the neck, the trachea was exposed and cannulated with PE 240 tubing, and the rat ventilated in room air ( 70-80 breaths/min). The chest was opened, PE 50 tubing with a small needle was inserted into the right ventricle, and the pressure was recorded on a Grass polygraph (model 7E). At the end of the pressure measurements, the lungs were perfused with autoclaved normal saline to remove blood. The left lung and the heart were placed in $10 \%$ buffered formaldehyde. The right lung was quickly frozen in liquid nitrogen and stored at $-80^{\circ} \mathrm{C}$ for transcriptomic analysis at a later date.

\subsection{Assessment of Right-Ventricular Hypertrophy (RVH)}

One week later, the heart was removed from formaldehyde and the atria were trimmed. The free wall of the right ventricle (RV) was separated from the left ventricle (LV) and the septum (S) and weighed. The RVH was calculated for all groups as follows:

$$
R V H^{(P H)} \equiv \overline{\left(\frac{R V}{L V+S}\right)_{\text {weight }}^{(P H)}} \overline{\left(\frac{R V}{L V+S}\right)_{\text {weight }}^{(\mathrm{CO})}} \quad \forall(P H)=(\mathrm{HO}),(\mathrm{CM}),(\mathrm{HM})
$$

Right-ventricular hypertrophy occurs when the average $\mathrm{RV} /(\mathrm{LV}+\mathrm{S})(\mathrm{PH}))$ is significantly $(p<0.05)$ larger than $\mathrm{RV} /(\mathrm{LV}+\mathrm{S})(\mathrm{CO})$ (i.e., RVH significantly larger than one). 


\subsection{Histology}

Formalin-preserved lung tissue was processed for paraffin block. Then, 5-6- $\mu \mathrm{m}$ sections were cut and stained with hematoxylin and eosin (H\&E) for evaluation of the pulmonary vasculature.

\subsection{Microarray}

Lungs were quickly removed, frozen in liquid nitrogen, and stored at $-80{ }^{\circ} \mathrm{C}$. Our optimized protocol [37,38] and the "multiple yellow" strategy [39] were used to profile each "condition" in four biological replicas. Briefly. total RNA was extracted with Qiagen RNeasy minikit, concentration was determined with a NanoDrop ND-2000 Spectrophotometer, and purity determined with an Agilent RNA 6000 Nano kit in an Agilent 2100 Bioanalyzer. Total RNA was then reverse-transcribed in the presence of $\mathrm{Cy} 3 / \mathrm{Cy} 5 \mathrm{dUTP}$ and the incorporation of fluorescent tags was determined again with the nanodrop. Differently labeled samples of biological replicates were hybridized overnight with Agilent 60 mer $4 \times 44 \mathrm{k}$ whole genome rat V2 arrays (\#G2519F). The arrays were scanned with an Agilent G2539A dual-laser scanner, and primary analysis was performed with (Agilent) Feature Extraction 11.1 software. All spots affected by local corruption or with foreground fluorescence less than twice the background were disregarded, and data were normalized and filtered following our standard procedure [40].

\subsection{Transcriptomic Analysis}

A gene was considered as significantly regulated if the absolute fold-change exceeded the cut-off calculated for that gene [41]. The cut-off (CUT, Equation (1)) accounts for the observed expression variability of that gene in the compared conditions and the existence of several spots probing it redundantly in the microarray. The non-uniform expression variability among the genes results from both the biological variability within biological replicas and the inherent technical noise. This strategy aims to substantially reduce both the positive and the negative false hits when using an arbitrary cut-off (e.g., 1.5×) for the fold-change. CUT (Equation (1)) adds correction for the groups of microarray spots redundantly probing the same gene.

$$
\begin{aligned}
& \mathrm{CUT}_{i}^{(P H)}=1+\frac{1}{2}(\underbrace{\left(\sqrt{\frac{r_{i}}{\chi^{2}\left(r_{i} ; 1-\varepsilon / 2\right)}}+\sqrt{\frac{r_{i}}{\chi^{2}\left(r_{i} ; \varepsilon / 2\right)}}\right)}_{\text {chi-square correction }}(\underbrace{\left.\sqrt{\frac{1}{R_{i}} \sum_{k=1}^{R_{i}}\left(\left(\frac{s_{i k}^{(P H)}}{\mu_{i k}^{(P H)}}\right)^{2}+\left(\frac{s_{i k}^{(\mathrm{CO})}}{\mu_{i k}^{(\mathrm{CO})}}\right)^{2}\right)}\right)}_{\text {pooled CV }}) \text { where : } \\
& (P H)=(H O),(C M),(H M) \\
& r_{i}=4 R_{i}-1=\text { number of degrees of freedom, } \mathrm{R}_{\mathrm{i}}=\text { number of spots probing the same gene } \mathrm{i} \\
& \chi^{2}=\text { chi-square score for } r_{i} \text { degrees of freedom and probability } \varepsilon(=0.05) \text { in this report } \\
& s_{i k}^{(\text {condition })}=\text { standard deviation of gene i probed by spot } \mathrm{k} \text { in the specified condition } \\
& \mu_{i k}^{\text {(condition) }}=\text { average expression of gene i probed by spot } \mathrm{k} \text { in the specified condition }
\end{aligned}
$$

Profiling four biological replicates allows independent assessment of (i) average expression level, (ii) expression variability, and (iii) expression coordination of each gene with each individual gene. Combination of these measures was used to determine the remodeling of the topology and interplay of the functional genomic fabrics. The genomic fabric was defined by us as the most inter-coordinated and stably expressed gene network responsible for selected biological processes [42].

\subsection{Pathway Analysis}

The genes pertaining to important functional pathways were selected from the maps developed by Kyoto Encyclopedia of Genes and Genomes (KEGG) [43]. Particular attention was given to the genes involved in oxidative phosphorylation (map 00190, ATPases, cytochrome c oxidases, NADH 
dehydrogenases), chemokine signaling pathway (map 04062), vascular smooth muscle contraction (map 04270), mitochondrion ribosomal proteins, and cell cycle (map 04110).

The corrected weighted pathway regulation (WPR) [44] was used to quantify the transcriptomic effects of the three PH models on the selected functional pathways.

$$
\begin{aligned}
& W P R_{\Gamma}^{(P H)}=\langle\mu_{i}^{(\mathrm{CO})} \underbrace{\left(\left|x_{i}^{(P H)}\right|-C U T_{i}^{(P H)}\right)}_{=0 \text { if }\left|x_{i}^{(P H)}\right|<C U T_{i}^{(P H)}} \times \underbrace{\left(1-p_{i}^{(P H)}\right)}_{\text {confidence of significant regulation }}, \text { all } \mathrm{i} \in \Gamma \\
& \langle\mathrm{A}\rangle=\text { median of } \mathrm{A} \text { for all genes within the functional pathway } \Gamma \\
& x_{i}^{(P H)}=\text { fold }- \text { change } \text { (negative for down - regulation in the } \mathrm{PH} \text { model with respect to } \mathrm{CTR} \\
& p_{i}^{(P H)}=\mathrm{p} \text { - value of the expression regulation of gene } \mathrm{i} \text { in the } \mathrm{PH} \text { model }
\end{aligned}
$$

WPR is more informative than the traditional percentage of regulated genes. WPR weights the contribution of each gene proportional to its normal (here, in the CO group) average expression, absolute fold-change (until the cut-off accounting for the combined contributions of the technical noise and biological variability), and confidence of the expression regulation.

Like in previous experiments with kidneys [45] and hearts of mice subjected to chronic hypoxia $[39,46,47]$, we computed the pair-wise Pearson correlation coefficient $\rho i j$ between the expression levels of all pairs of expressed genes $i$ and $j$ in biological replicas of each condition. As speculated in previous papers $[48,49]$, strong expression correlation of two genes may represent a kind of "transcriptomic stoichiometry" aiming to optimize the pathway involving the encoded proteins. Expressions of $(p<0.05)$ statistically significantly synergistically expressed genes ( $\rho i j>0.950)$ oscillate in phase (both genes increase and decrease their expression simultaneously), while expressions of antagonistically expressed genes $(\rho i j<-0.950)$ manifest opposite tendencies (when one increases, the other decreases). Genes with $|\rho i j|<0.025$ are considered independently expressed. Different from the traditional cluster analysis that correlates the genes according to their similar behavior across various conditions or time points, we compute the correlation only between the expression levels in biological replicas of the same condition to determine "stoichiometric gene networks" [49].

The influence of a given gene i toward a particular pathway $\Gamma$ was evaluated by its average coordination power $(\mathrm{CP})$ against the expressions of the pathway $\Gamma$ genes.

$$
C P_{i ; \Gamma}^{(\text {condition })}=\left\langle\rho_{i j}^{(\text {condition })}\right\rangle_{j \in \Gamma} \times 100 / \% .
$$

$\mathrm{CP}$ takes values from $-100 \%$ (all $\Gamma$-genes perfectly negatively correlated with gene i) to $100 \%$ (all $\Gamma$-genes perfectly positively correlated with gene i). A neutral gene toward that pathway has the $\mathrm{CP}$ close to zero, indicating that either almost all correlations are null or the positives are balanced by the negatives.

Here, we introduce a new measure, termed gene pair prominence (GPP), to quantify the relevance of gene interplays in each condition. The two genes can be from the same or from two different functional pathways. GPP takes values from $-100 \%$ for the most prominent, negatively correlated genes to $100 \%$ for the most prominent, positively correlated genes in that condition. In order to simplify the landscape, GPP was considered zero for gene pairs whose absolute Pearson product-moment correlation coefficient between their expression levels in the four biological replicas of that condition was not significant $\left(\left|\rho_{i j}\right|<0.950\right)$.

$$
\begin{aligned}
& \operatorname{GPP}_{i j}^{(\text {condition })}=\left\{\begin{array}{lll}
\frac{\mu_{i}^{(\text {condition })} \rho_{i j}^{(\text {condition })} \mu_{j}^{(\text {condition })}}{\max \left|\mu_{i}^{(\text {condition })} \rho_{i j}^{(\text {condition })} \mu_{j}^{(\text {condition })}\right|_{i \in \Gamma_{1} j \in \Gamma_{2}}} \times 100 \% & \text { if }\left|\rho_{i j}^{(\text {condition })}\right|>0.950 \\
0 & \text { if }\left|\rho_{i j}^{(\text {condition })}\right|<0.950
\end{array}\right. \text {, where : } \\
& \rho_{i j}^{(\text {condition })} \text { is the pair - wise Pearson correlation coefficient of the expression levels of genes } i \in \Gamma_{1}, j \in \Gamma_{2} \\
& \text { condition }=\mathrm{CO}, \mathrm{HO}, \mathrm{CM}, \mathrm{HM} ; \Gamma_{1}, \Gamma_{2}=\text { functional pathways; }|\mathrm{X}|=\text { absolute value of } \mathrm{X}
\end{aligned}
$$




\section{Results}

\subsection{Decreased Weight Gain}

The four-week weight gain in the control group was $(204 \pm 23) \mathrm{g}$. All PH groups had significantly lower weight gains as presented in Figure 1a; the lowest was observed in MCT-treated rats exposed to hypoxia, i.e., group HM (WG $=33.6 \pm 16.0) \mathrm{g}$.

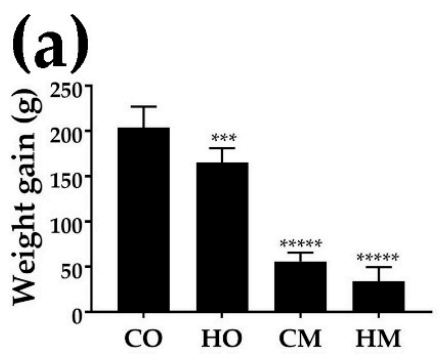

(d)
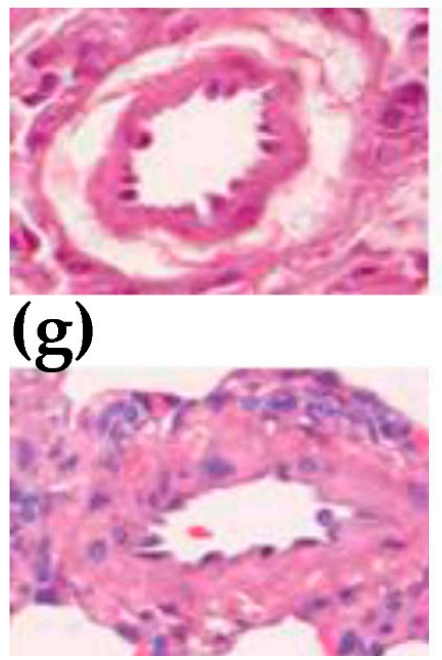

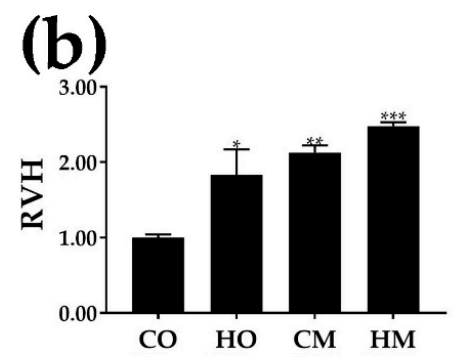

(e)

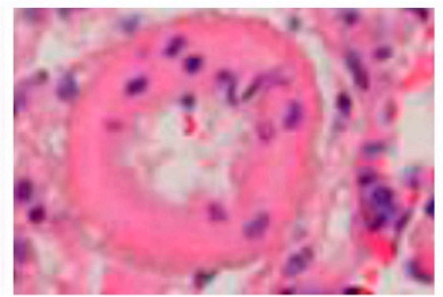

(h)

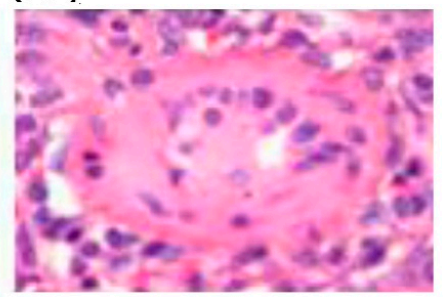

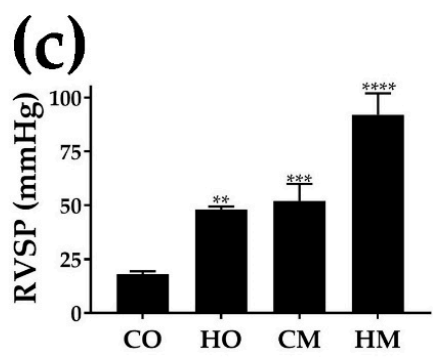

(f)

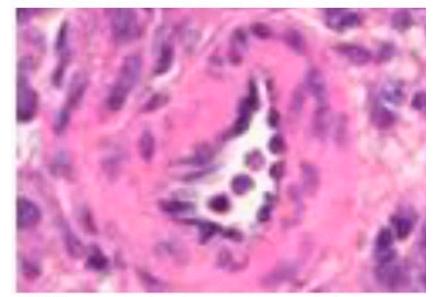

(i)

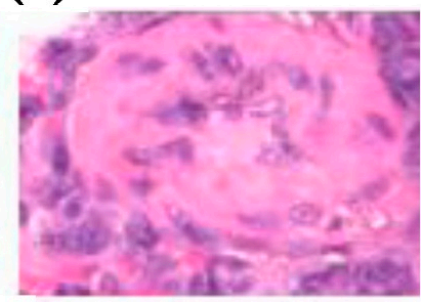

Figure 1. Effects of the pulmonary hypertension on (a) weight gain $(n=8)$, (b) right-ventricle hypertrophy (RVH, dimensionless measure) $(n=8)$, (c) right-ventricle systolic pressure (RVSP) $(n=8)$, and $(\mathbf{d}-\mathbf{i})$ histology of the pulmonary arteries. Hematoxylin and eosin $(\mathrm{H} \& \mathrm{E})$-stained sections from lungs of rats from the groups: control $(\mathrm{CO})(\mathbf{d})$, hypoxia $(\mathrm{HO})(\mathbf{e})$, monocrotaline $(\mathrm{CM})(\mathbf{f})$, and monocrotaline and hypoxia (HM) $(\mathbf{g}-\mathbf{i})$. Note in (h) and (i) that the pulmonary arteries exhibit luminal obstruction. Statistical significance $\left(t\right.$-test): ${ }^{*}(p<0.05),{ }^{* *}(p<0.01),{ }^{* * *}(p<0.005),{ }^{* * * *}(p<0.001),{ }^{* * * * *}(p<0.0001)$.

\subsection{Right-Ventricle Hypertrophy}

Figure $1 \mathrm{~b}$ presents the significant increase in ratio between the right-ventricle weight and the sum of the left-ventricle and septum weights in the three PH models as normalized to the RV/(LV + $S)$ in the control group. Note that right-ventricle hypertrophy was statistically significant in all three experimental models.

\subsection{Increased Right-Ventricle Systolic Pressure}

As depicted in Figure 1c, RVSP was significantly increased in all PH groups (HO, CM, HM) compared to the controls $(\mathrm{CO})$. While the difference between $\mathrm{HO}$ and $\mathrm{CM}$ groups was not statistically significant ( $p=0.364$ ), the differences between the HM and HO groups ( $p=0.000127)$ and between HM and CM groups $(p=0.00078)$ were highly significant. 


\subsection{Histological Alterations}

Figure 1d-i present H\&E-stained pulmonary arteries (external diameter, 42-101 $\mu \mathrm{m}$ ) from the controls (D) and the experimental groups: HO (e), CM (f), and HM (g, h, i). Pulmonary arteries from $\mathrm{CM}$ and $\mathrm{HO}$ show substantial medial wall thickening compared with the control. The arteries from the HM group show further medial wall thickening, and as seen in (h) and (i), exhibit neointima formation and occlusion of the lumen.

\subsection{Overview of the Transcriptomic Alterations}

Raw and processed gene expression results were deposited and are publicly available at [50]. Figure $2 \mathrm{a}, \mathrm{b}$ indicate that all three experimental $\mathrm{PH}$ conditions regulated large numbers of genes and produced large weighted pathway regulation (WPR) scores. The overall transcriptomic alterations (\% of ALL REG and WPR) were consistent with the alterations in weight gain, RVH, and RVSP data. Thus, MCT alone had a slightly larger effect than hypoxia alone; when MCT-treated rats were exposed to hypoxia, the alterations were substantially larger. Figure 2c presents the WPR scores of some interesting groups of genes involved in respiration. Figure $2 \mathrm{~d}$ presents the significant fold-changes of genes whose regulation is often associated with $\mathrm{PH}$. Remarkably, in all three rat models of PH, Cav1 was overexpressed, by $13.18 \times$ in $\mathrm{HO}, 39.14 \times$ in $\mathrm{CM}$, and $79.06 \times$ in $\mathrm{HM}$, with a substantial increase in the HM group. We found also that upregulation of Cav1 was accompanied by the upregulation of Nos3 (by $4.21 \times$ in $\mathrm{HM}$ ) and upregulation of Mmp2 (by 9.14× in HO, 33.59× in CM, and 81.47× in HM group). The vast majority of the regulated genes by separate exposure to either hypoxia or MCT were altered in the same direction. However, as presented in Figure 2e, few of them were oppositely regulated. Interestingly, when hypoxia and MCT were combined (as in HM), the regulation mostly followed the effects of the MCT exposure alone but with a larger fold-change (except for Plcb4 whose regulation in the HM group was opposite to regulations in both $\mathrm{HO}$ and $\mathrm{CM}$ groups).

\subsection{Regulation of the Immune-Inflammatory Response}

We found that PH regulated the expression of numerous genes involved in the (KEGG-determined map 04062) chemokine signaling pathway (Table 1). Table S1 in the Supplementary presents other immune-inflammatory response genes (chemokines, cytokines, cytokine receptors, interferons, interleukins, and tumor necrosis factors) that were significantly regulated in at least one of the three rat PH models. Importantly, compared to the traditional standard of uniform $1.5 \times$ absolute fold-change, our procedure to attach fold-change cut-offs to every single gene in each comparison identified additional regulated genes and eliminated false hits. 


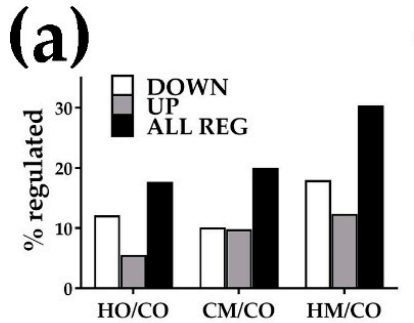

(d)

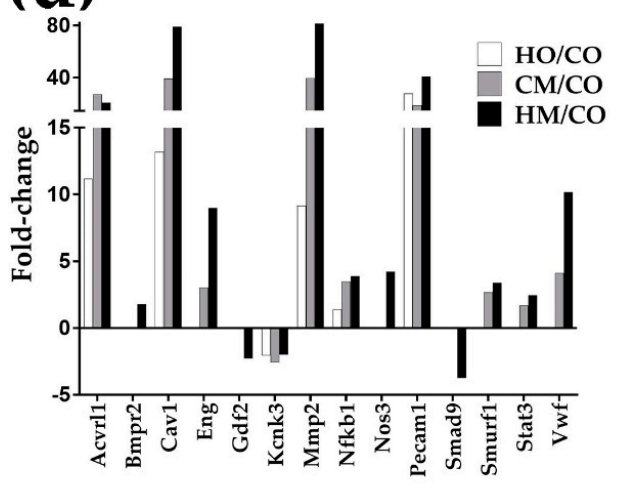

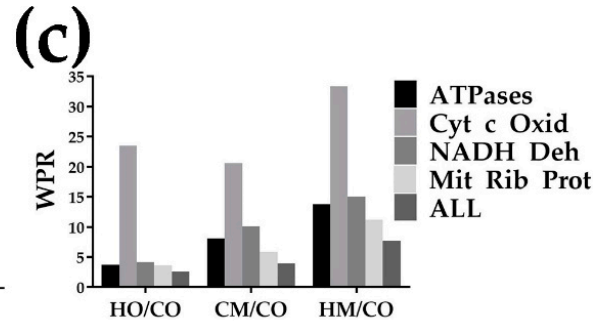

(e)

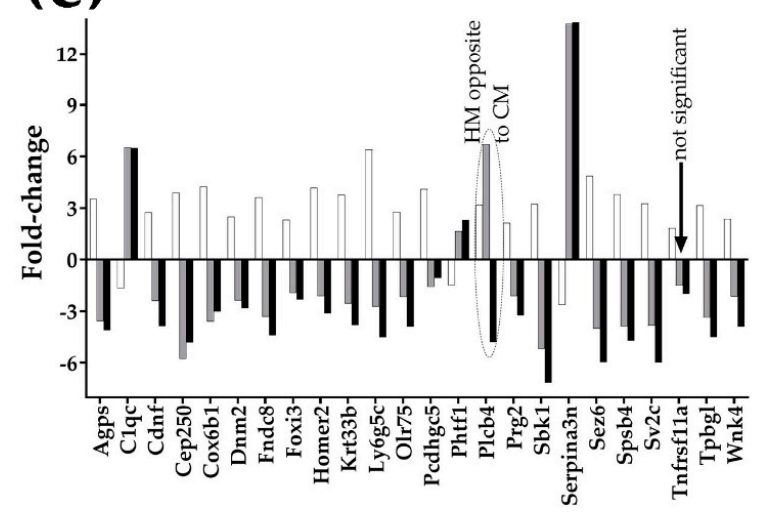

Figure 2. Transcriptomic alterations: (a) number of regulated genes; (b) weighted pathway regulation of all genes; (c) weighted pathway regulation for some important groups of genes. Pathways: Cyt c Oxid = cytochrome $\mathrm{c}$ oxidases, NADH Deh $=$ NADH dehydrogenases, Mit Rib Prot $=$ mitochondrial ribosomal proteins. Note that Cyt c Oxid was by far the most altered group of respiratory genes. $\mathrm{HO} / \mathrm{CO}$, $\mathrm{CM} / \mathrm{CO}, \mathrm{HM} / \mathrm{CO}=$ expression fold-change (negative for downregulation) in the indicated comparison; (d) statistically significant fold-changes of genes whose altered structure and/or expression is often associated with PH. Genes: Acorl1 (activin A receptor type II-like 1), Bmpr2 (bone morphogenetic protein receptor, type II (serine/threonine kinase)), Cav1 (caveolin 1, caveolae protein), Eng (endoglin), Gdf2 (growth differentiation factor 2), Kcnk3 (potassium channel, subfamily K, member 3), Mmp2 (matrix metallopeptidase 2), Nfkb1 (nuclear factor NF-kappa-B p105 subunit), Nos3 (nitric oxide synthase 3, endothelial cell), Pecam1 (platelet/endothelial cell adhesion molecule 1), SMAD9 (SMAD family member 9), Smurf1 (SMAD-specific E3 ubiquitin protein ligase 1), Stat3 (signal transducer and activator of transcription 3 (acute-phase response factor)), Vwf (von Willebrand factor); (e) significant opposite regulations. Genes: Agps (alkylglycerone phosphate synthase), C1qc (complement component 1, q subcomponent, C chain), Cdnf (cerebral dopamine neurotrophic factor), Cep250 (centrosomal protein 250), Cox6b1 (cytochrome c oxidase subunit 6B1), Dnm2 (dynamin 2), Fndc8 (fibronectin type III domain-containing 8), Foxi3 (forkhead box I3), Homer2 (homer homolog 2), Krt33b (keratin 33B), Ly6g5c (lymphocyte antigen 6 complex, locus G5C), Olr75 (olfactory receptor 75), Pcdhgc5 (protocadherin $\gamma$ subfamily C , 5), Phtf1 (putative homeodomain transcription factor 1), Plcb4 (phospholipase C, $\beta$ 4), Prg2 (proteoglycan 2, bone marrow), Sbk1 (SH3-binding domain kinase 1), Serpina3n (serine), Sez6 (seizure-related 6 homolog), Spsb4 (splA/ryanodine receptor domain and SOCS box-containing 4), Sv2c (synaptic vesicle glycoprotein 2c), Tnfrsf11a (tumor necrosis factor receptor superfamily, member 1a), Tpbgl (trophoblast glycoprotein-like), Wnk4 (WNK lysine-deficient protein kinase 4). 
Table 1. Regulation of the chemokine signaling pathway (Kyoto Encyclopedia of Genes and Genomes (KEGG), map rno04062) genes. Significant (larger than cut-off (CUT)) absolute fold-changes are in bold positive numbers for upregulated and bold negative numbers for downregulated. Note the range of the CUTs, from $1.24 \times$ (for the regulation of Rhoa in HM vs. CO) to $3.60 \times$ (for the regulation of Nfkbia in $\mathrm{HO}$ vs. $\mathrm{CO}$ ). Our procedure to determine the cut-off for the absolute fold-change for every gene in each comparison instead of using a fixed cut-off (like 1.5×) identified additional regulated genes (, e.g., Ccr1l1 in $\mathrm{HO} / \mathrm{CO}$ ). It also eliminated the false regulations (e.g., Bcar1 in $\mathrm{HO} / \mathrm{CO}$ ), whose absolute (although over 1.5×) fold-change was below the CUT (2.98) computed for that gene in the compared conditions.

\begin{tabular}{|c|c|c|c|c|c|c|c|}
\hline Gene & Description & $\mathrm{HO} / \mathrm{CO}$ & CUT & $\mathrm{CM} / \mathrm{CO}$ & CUT & $\mathrm{HM} / \mathrm{CO}$ & CUT \\
\hline Adcy 2 & Adenylate cyclase 2 (brain) & -4.24 & 2.32 & -4.72 & 2.33 & -4.21 & 2.34 \\
\hline Akt1 & V-akt murine thymoma viral oncogene homolog 1 & -1.42 & 1.61 & 1.09 & 1.94 & 1.80 & 1.78 \\
\hline Arrb1 & Arrestin, $\beta 1$ & -9.55 & 2.86 & -41.04 & 2.39 & -52.82 & 2.53 \\
\hline Arrb2 & Arrestin, $\beta 2$ & -1.38 & 2.11 & 3.37 & 2.54 & 2.95 & 2.24 \\
\hline Bcar1 & Breast cancer anti-estrogen resistance 1 & 1.74 & 2.98 & 5.27 & 2.68 & 10.39 & 1.83 \\
\hline Ccl21 & Chemokine (C-C motif) ligand 21 & 3.26 & 2.70 & 79.95 & 3.31 & 247.07 & 1.34 \\
\hline Ccl24 & Chemokine (C-C motif) ligand 24 & 5.07 & 3.07 & 10.24 & 2.36 & 5.74 & 2.13 \\
\hline Ccl27 & Chemokine (C-C motif) ligand 27 & 1.18 & 3.00 & -7.76 & 1.85 & -10.14 & 2.14 \\
\hline Ccl5 & Chemokine (C-C motif) ligand 5 & -1.35 & 1.85 & 4.56 & 2.45 & 4.40 & 1.65 \\
\hline Ccl6 & C-C motif chemokine 6 & 7.53 & 3.32 & 22.93 & 2.72 & 38.26 & 1.98 \\
\hline Ccl9 & Chemokine (C-C motif) ligand 9 & -1.18 & 1.88 & 3.75 & 2.68 & 2.16 & 1.82 \\
\hline Cor1l1 & Chemokine (C-C motif) receptor 1-like 1 & -1.48 & 1.46 & -1.66 & 1.83 & -2.77 & 1.80 \\
\hline Ccr9 & Chemokine (C-C motif) receptor 9 & 4.01 & 2.84 & 10.35 & 2.65 & 1.29 & 1.78 \\
\hline$C x 3 c r 1$ & Chemokine (C-X3-C motif) receptor 1 & 2.48 & 2.96 & 2.65 & 2.99 & -2.53 & 2.35 \\
\hline Cxcl12 & Chemokine (C-X-C motif) ligand 12 & 1.77 & 2.38 & 3.77 & 2.41 & 60.14 & 1.83 \\
\hline $\mathrm{Cxcl3}$ & Chemokine (C-X-C motif) ligand 3 & 1.61 & 2.33 & 3.93 & 3.13 & 3.33 & 1.93 \\
\hline Gnai2 & $\begin{array}{l}\text { Guanine nucleotide binding protein (G protein), } \\
\qquad \alpha \text { inhibiting } 2\end{array}$ & 4.30 & 3.59 & 5.79 & 2.95 & 10.05 & 2.13 \\
\hline Gnb1 & $\begin{array}{l}\text { Guanine nucleotide binding protein (G protein), } \\
\qquad \text { polypeptide } 1\end{array}$ & -4.22 & 2.37 & -1.47 & 2.80 & 1.23 & 2.19 \\
\hline Gnb2 & $\begin{array}{l}\text { Guanine nucleotide binding protein ( } G \text { protein), } \\
\qquad \beta \text { polypeptide } 2\end{array}$ & 2.15 & 2.99 & 3.44 & 2.49 & 6.23 & 1.70 \\
\hline Gnb3 & $\begin{array}{l}\text { Guanine nucleotide binding protein (G protein), } \\
\qquad \text { polypeptide } 3\end{array}$ & -3.33 & 2.17 & -6.18 & 2.40 & -11.78 & 2.42 \\
\hline Gng13 & $\begin{array}{l}\text { Guanine nucleotide binding protein (G protein), } \\
\qquad \gamma 13\end{array}$ & -2.64 & 2.43 & -3.56 & 2.36 & -2.33 & 2.10 \\
\hline Gng3 & $\begin{array}{l}\text { Guanine nucleotide binding protein (G protein), } \\
\qquad \gamma 3\end{array}$ & -22.18 & 2.46 & -21.14 & 2.51 & -32.06 & 2.44 \\
\hline Gng4 & $\begin{array}{l}\text { guanine nucleotide binding protein (G protein), } \\
\qquad \gamma 4 \text { subunit }\end{array}$ & -1.24 & 1.46 & -1.29 & 1.77 & -2.19 & 1.71 \\
\hline Gngt2 & $\begin{array}{l}\text { Guanine nucleotide binding protein (G protein), } \\
\gamma \text { transducing activity polypeptide } 2\end{array}$ & 1.76 & 2.62 & 7.16 & 2.75 & 11.11 & 1.63 \\
\hline Grb2 & Growth factor receptor bound protein 2 & 4.31 & 2.79 & 3.69 & 2.75 & 6.32 & 1.87 \\
\hline Grk6 & G protein-coupled receptor kinase 6 & -3.00 & 2.59 & -1.04 & 2.69 & 1.69 & 2.07 \\
\hline Gsk3a & Glycogen synthase kinase $3 \alpha$ & -4.67 & 2.17 & -4.44 & 2.31 & -7.27 & 2.21 \\
\hline Mapk3 & Mitogen activated protein kinase 3 & 1.72 & 2.92 & -3.71 & 2.05 & -3.42 & 1.89 \\
\hline Nfkbia & $\begin{array}{l}\text { Nuclear factor of kappa light polypeptide gene } \\
\text { enhancer in B-cells inhibitor, } \alpha\end{array}$ & 1.92 & 3.60 & 5.56 & 3.03 & 9.00 & 2.20 \\
\hline Nfkbid & NF- $\kappa B$ inhibitor delta & -1.79 & 1.64 & -2.08 & 1.89 & -3.25 & 1.85 \\
\hline Pak1 & P21 protein (Cdc42/Rac)-activated kinase 1 & -1.79 & 2.19 & -3.31 & 2.17 & -3.17 & 2.15 \\
\hline Pik3r1 & $\begin{array}{l}\text { Phosphoinositide-3-kinase, regulatory subunit } \\
\qquad 1(\alpha)\end{array}$ & 1.20 & 2.03 & 2.77 & 2.28 & 4.25 & 1.28 \\
\hline Pik3r5 & Phosphoinositide-3-kinase, regulatory subunit 5 & -11.53 & 2.66 & -5.87 & 2.40 & -7.66 & 2.38 \\
\hline Plcb4 & Phospholipase C, $\beta 4$ & 3.18 & 2.86 & 6.70 & 2.99 & -4.79 & 2.12 \\
\hline
\end{tabular}


Table 1. Cont.

\begin{tabular}{|c|c|c|c|c|c|c|c|}
\hline Gene & Description & $\mathrm{HO} / \mathrm{CO}$ & CUT & $\mathrm{CM} / \mathrm{CO}$ & CUT & $\mathrm{HM} / \mathrm{CO}$ & CUT \\
\hline Ppbp & $\begin{array}{l}\text { Pro-platelet basic protein (chemokine (C-X-C } \\
\text { motif) ligand } 7)\end{array}$ & -1.05 & 1.41 & -1.16 & 2.11 & -3.06 & 2.13 \\
\hline$P t k 2 b$ & PTK2B protein tyrosine kinase $2 \beta$ & -12.47 & 2.45 & -6.89 & 2.36 & -8.51 & 2.34 \\
\hline Rap1b & RAP1B, member of RAS oncogene family & -3.04 & 2.84 & -1.84 & 3.17 & -1.17 & 2.37 \\
\hline Rela & $\begin{array}{l}\text { V-rel reticuloendotheliosis viral oncogene } \\
\text { homolog A (avian) }\end{array}$ & -3.38 & 2.07 & -1.15 & 2.29 & 1.22 & 1.98 \\
\hline Rhoa & Ras homolog gene family, member A & 7.00 & 2.80 & 6.78 & 2.52 & 9.21 & 1.24 \\
\hline Shc1 & $\begin{array}{l}\text { SHC (Src homology } 2 \text { domain containing) } \\
\text { transforming protein } 1\end{array}$ & -2.71 & 2.09 & -4.11 & 2.03 & -4.94 & 2.08 \\
\hline Sos1 & Son of sevenless homolog 1 (Drosophila) & 1.02 & 1.99 & 2.07 & 2.49 & -2.86 & 1.77 \\
\hline Tiam1 & T-cell lymphoma invasion and metastasis 1 & -2.79 & 1.75 & -2.67 & 2.13 & -4.85 & 1.95 \\
\hline Vav2 & Vav 2 guanine nucleotide exchange factor & 2.06 & 2.74 & 3.44 & 2.43 & 6.02 & 1.45 \\
\hline Xcl1 & Chemokine (C motif) ligand 1 & -1.51 & 1.96 & -1.53 & 2.20 & -3.49 & 2.03 \\
\hline
\end{tabular}

\subsection{Regulation of the Vascular Smooth Muscle Contraction Pathway}

Figure 3 presents the regulation of the 122 quantified genes involved in the (KEGG-determined map 04270) vascular smooth muscle contraction pathway in the three PH models. Note the substantially increased number of regulated genes when the MCT-treated rats were exposed to hypoxia $(30 \%$ up + $49 \%$ down, Figure 3a) compared to when they were exposed to only hypoxia ( $16 \%$ up $+14 \%$ down, Figure $3 \mathrm{~b}$ ) or treated with MCT ( $26 \%$ up $+16 \%$ down, Figure $3 \mathrm{c})$. The percentages of all regulated genes in this pathway ( $30 \%$ in $\mathrm{HO}, 42 \%$ in $\mathrm{CM}$, and $79 \%$ in $\mathrm{HM}$ ) were notably larger than the percentages of all regulated genes in the entire transcriptome (18\% in $\mathrm{HO}, 20 \%$ in $\mathrm{CM}$, and $30 \%$ in $\mathrm{HM}$ ) as illustrated in Figure 2a. Panels 3d, 3e, and 3f present the statistically significant $(p<0.00001)$ correlations of the fold-changes of the VSMC genes in the three PH models. The analysis revealed a larger Pearson correlation coefficient between the regulation of VSMC genes in CM and HM $(\rho=0.938)$ than between $\mathrm{CM}$ and $\mathrm{HO}(\rho=0.831)$, and HM and HO $(\rho=0.801)$. 


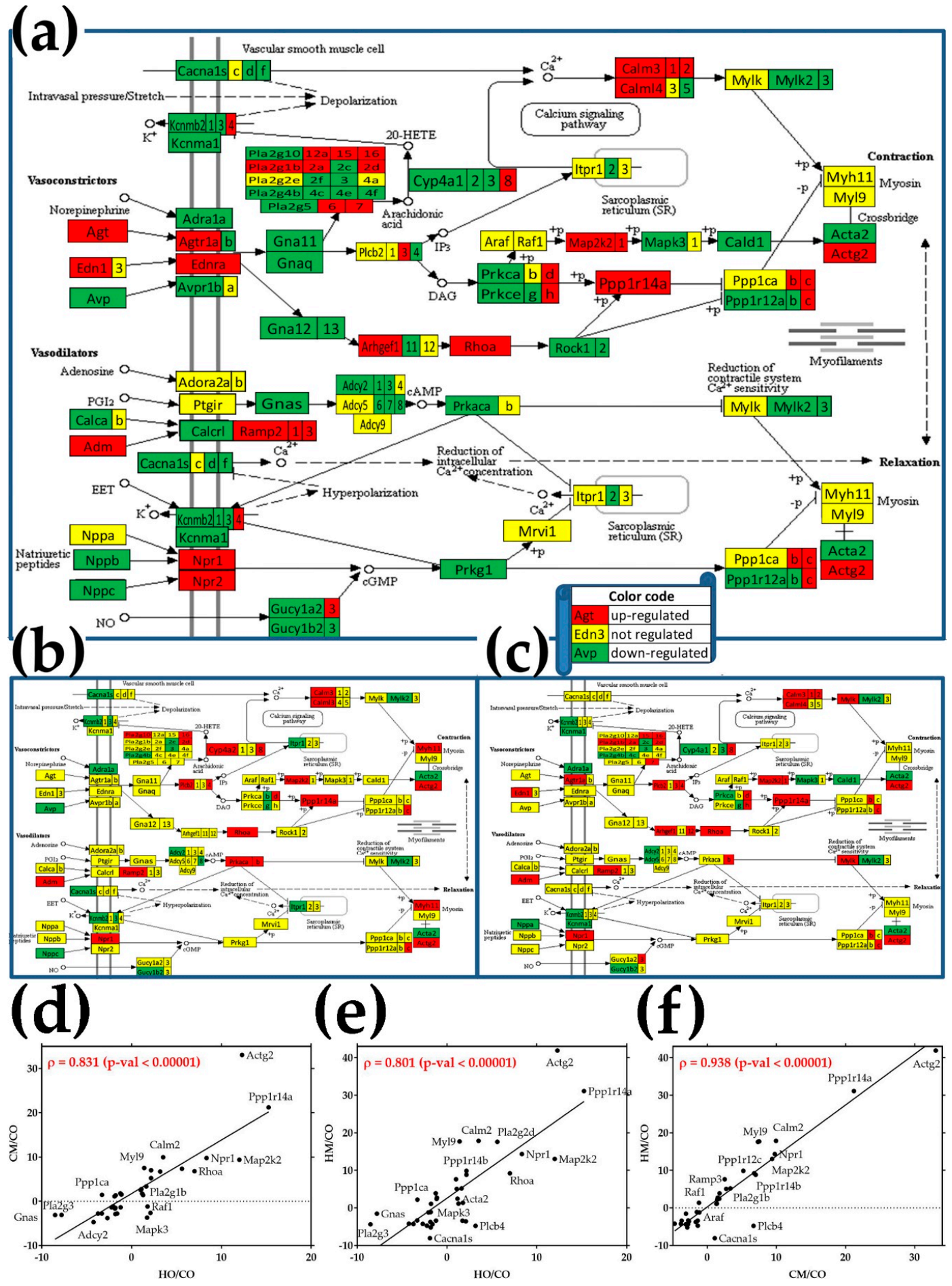

Figure 3. Regulation of the vascular smooth muscle contraction pathway. (a) Rats treated with monocrotaline (MCT) and exposed to hypoxia (HM); (b) rats exposed to only hypoxia (HO); (c) rats treated with monocrotaline only (CM). Regulated genes: Acta2 (smooth muscle $\alpha$-actin), Actg2 (actin, $\gamma$ 2, smooth muscle, enteric), Adcy2 (adenylate cyclase 2), Adora2a (adenosine A2a receptor), Agtr1a (angiotensin II receptor, type 1a), Ang (angiogenin), Araf (v-raf murine sarcoma 3611 viral oncogene homolog), Avp (arginine vasopressin), Cacna1d/s (calcium channel, voltage-dependent, L type, $\alpha$ 1D/S 
Pla2g1b ( subunit), Cald1 (caldesmon 1), Calm2 (calmodulin 2), Cyp4a1/8 (cytochrome P450, family 4 , subfamily a, polypeptide 1/8), Gnas (GNAS complex locus), Gucy1b2 (guanylate cyclase 1, soluble, $\beta$ 2), Itpr1 (inositol 1,4,5-trisphosphate receptor, type 1), Kcnmb2 (potassium large conductance calcium-activated channel, subfamily M, $\beta$ member 2), Map2k2 (mitogen-activated protein kinase kinase 2), Mapk3 (mitogen-activated protein kinase 3), Myl9 (myosin, light chain 9, regulatory), Mylk2 (myosin light chain kinase 2), Npr1/2 (natriuretic peptide receptor guanylate cyclase A/B), phospholipase A2, group IB, pancreas), phospholipases A2 (Pla2g2d, Pla2g3, Pla2g4b, Pla2g6), Plcb4 (phospholipase C, $\beta$ 4), Ppp1ca (protein phosphatase 1, catalytic subunit, $\alpha$ isozyme), Ppp1r12c/14a/14b (protein phosphatase 1, regulatory subunit 12C/14A/14B), Prkca/e (protein kinase C, $\alpha /$ epsilon), Ptgir (prostaglandin I2 (prostacyclin) receptor (IP)), Raf1 (v-raf-leukemia viral oncogene 1), Ramp1/3 (receptor (G protein-coupled) activity modifying protein $1 / 3$ ), Rhoa (Ras homolog family member A); (d) correlation of fold-changes of VSMS genes in CM and $\mathrm{HO}$ with respect to $\mathrm{CO}$; (e) correlation of fold-changes of vascular smooth muscle cell (VSMC) genes in $\mathrm{HM}$ and $\mathrm{HO}$ with respect to $\mathrm{CO}$; (f) correlation of fold-changes of VSMC genes in HM and CM with respect to CO. Note the highly significant correlation of VSMC genes alterations in the three pulmonary hypertension $(\mathrm{PH})$ models. Only genes with significant regulation in at least one PH model were included. Gene symbols were attached where the space allowed good readability.

\subsection{Regulation of the Cell-Cycle Pathway}

Figure 4 presents the regulation of the 112 quantified genes responsible for the (KEGG-determined map 04110) cell-cycle pathway in the three PH models with respect to control. As expected, many more genes were regulated in the lungs of MCT-treated rats exposed to hypoxia ( $36 \%$ up $+42 \%$ down, Figure $4 \mathrm{a})$ than in those of rats exposed to only hypoxia ( $7 \%$ up $+16 \%$ down, Figure $4 \mathrm{~b}$ ) or treated with monocrotaline alone ( $25 \%$ up $+11 \%$ down, Figure $4 \mathrm{c})$. Of note are the much higher percentages of regulated genes in the cell-cycle pathway (23\% in $\mathrm{HO}, 36 \%$ in CM and $78 \%$ in $\mathrm{HM}$ ) than the percentages of regulated genes in the entire transcriptome ( $18 \%$ in $\mathrm{HO}, 20 \%$ in $\mathrm{CM}$ and $30 \%$ in $\mathrm{HM}$ ) as illustrated in Figure 2a.

Genes were regulated in both DNA replication phase (S) and mitosis phase (M), as well as during the temporal separation gaps (denoted by G1 and G2 in Figure 4a). Interestingly, all components of the minichromosome maintenance complex $(\mathrm{Mcm})$ were regulated in MCT-treated rats exposed to hypoxia, with downregulation of $\mathrm{Mcm} 3$ and upregulation of $\mathrm{Mcm} 7$ consistent in the other two $\mathrm{PH}$ groups. In contrast, while no subunit of the origin recognition complex (Orc) was regulated by MCT administration and only Orc4 was downregulated by hypoxia, when MCT-treated animals were exposed to hypoxia, all but Orc4 Orc subunits were regulated. Panels $4 \mathrm{~d}, 4 \mathrm{e}$, and $4 \mathrm{f}$ present the statistically significant correlations of the fold-changes of the CC genes in the three PH models. The analysis revealed a larger Pearson correlation coefficient between the regulation of CC genes in CM and HM $(\rho=0.976)$ than between CM and HO $(\rho=0.602)$ or HM and $\mathrm{HO}(\rho=0.602)$. 

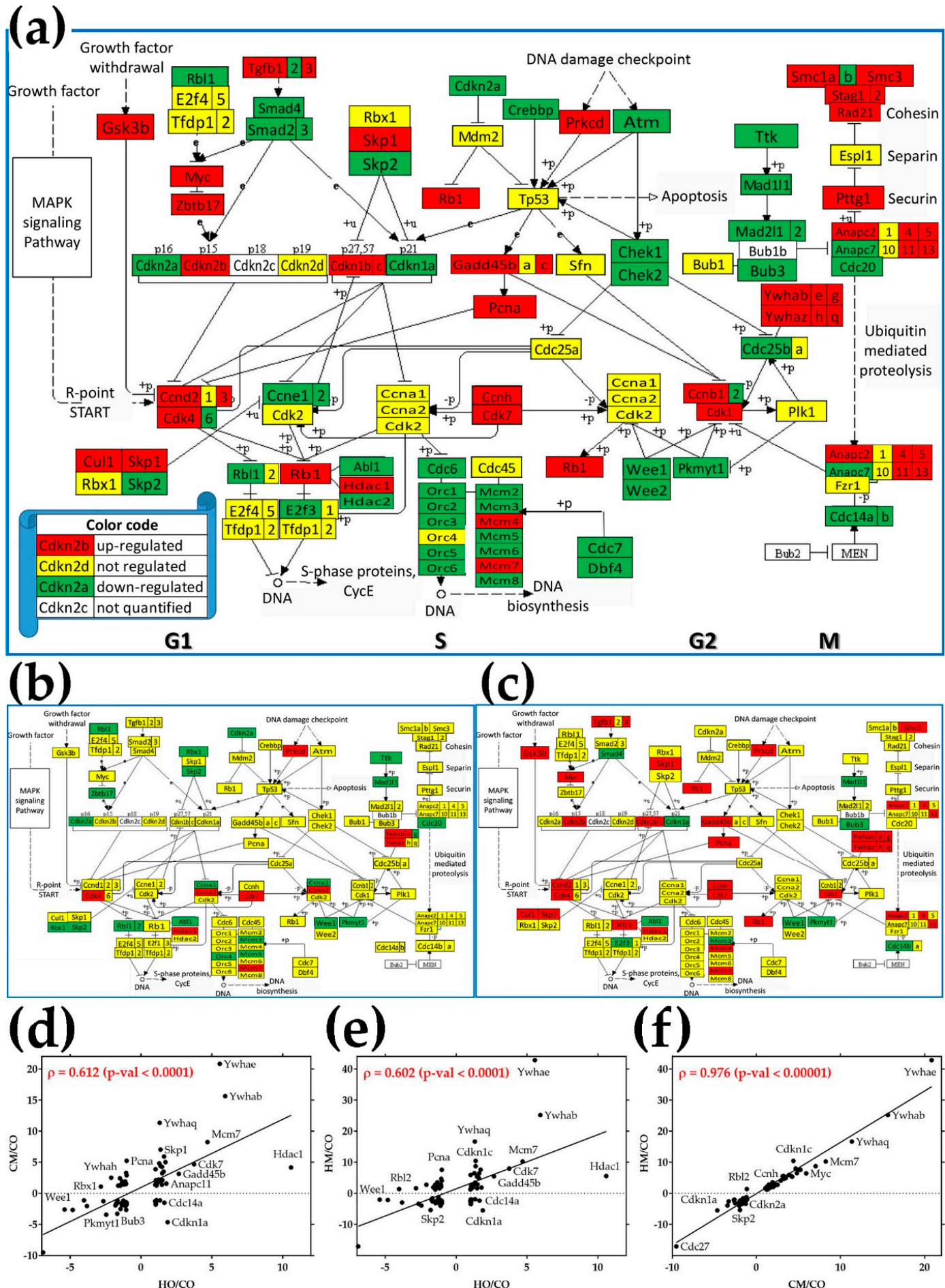

\section{(e)}

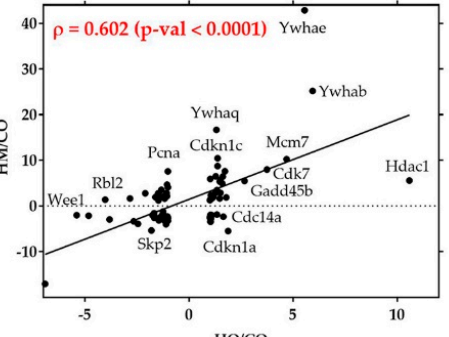

(f)

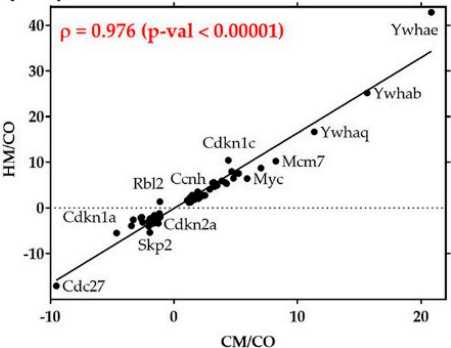

Figure 4. Regulation of the cell-cycle (CC) pathway. (a) Rats treated with MCT and exposed to hypoxia $(\mathrm{HM})$; (b) rats exposed to only hypoxia $(\mathrm{HO})$; (c) rats treated with monocrotaline only $(\mathrm{CM})$. Regulated genes: $A b l 1$ (C-abl oncogene 1, non-receptor tyrosine kinase), subunits of the anaphase promoting complex (Anapc2, Anapc4, Anapc5, Anapc7, Anapc11, Anapc13), Atm (ataxia telangiectasia mutated homolog), Bub3 (budding uninhibited by benzimidazoles 3 homolog), cyclins (Ccnb1, Ccnb2, Ccnd2, Cond3, Ccne1, Ccne2, Ccnh), cell division cycles (Cdc14a, Cdc14b, Cdc20, Cdc25a, Cdc25b, Cdc6), cyclin- 
dependent kinases (Cdk1,Cdk4,Cdk6,Cdk7), cyclin-dependent kinase inhibitors (Cdkn1a, Cdkn1b, Cdkn1c, Cdkn2a, Cdkn2b), checkpoint kinases (Chek1, Chek2), Cul1 (culin 1), Dbf4 (DBF4 homolog), Gsk3b (glycogen synthase kinase $3 \beta$ ), E2f3 (E2F transcription factor 3), growth arrest and DNA-damage-inducible (Gadd45b, Gadd45c), histone deacetylases (Hdac1, Hdac2), MAD2 mitotic arrest deficient-likes (Mad2l1, Mad2l2), components of the minichromosome maintenance complex (Mcm2, Mcm3, Mcm4, Mcm5, Mcm6, Mcm7, Mcm8), Myc (myelocytomatosis oncogene), subunits of the origin recognition complex (Orc1, Orc2, Orc3, Orc4, Orc5, Orc6), Pcna (proliferating cell nuclear antigen), Pkmyt1 (protein kinase, membrane associated tyrosine/threonine 1), Prkcd (protein kinase C, delta), Rad21 (RAD21 homolog), retinoblastomas $(R b 1, R b l 1), S k p 1 / 2$ (S-phase kinase-associated protein 1/2), structural maintenance of chromosomes (Smc1a, Smc1b,Smc3), SMAD family members (Smad2, Smad3, Smad4), stromal antigens (Stag1, Stag2), transforming growth factors $\beta$ (Tgfb1, Tgfb2, Tgfb3), Wee1 (WEE1 G2 checkpoint kinase), Wee2 (oocyte meiosis inhibiting kinase), tyrosine 3-monooxygenase/tryptophan 5-monooxygenase activation proteins (Ywhab, Ywhae, Ywhag, Ywhah, Ywhaq, Ywhaz), Zbtb17 (zinc finger and BTB domain-containing 17); (d) correlation of fold-changes of CC genes in CM and $\mathrm{HO}$ with respect to $\mathrm{CO}$; (e) correlation of fold-changes of $\mathrm{CC}$ genes in $\mathrm{HM}$ and $\mathrm{HO}$ with respect to $\mathrm{CO}$; (f) correlation of fold-changes of CC genes in HM and CM with respect to CO. Note the highly significant correlation of VSMC genes alterations in the three PH models. Only genes with significant regulation in at least one PH model were included. Gene symbols were attached where the space allowed good readability.

\subsection{Alteration of Cellular Respiration}

Particular attention was given to the regulation of the major groups of genes involved in the active ionic transport across the plasma membrane (ATPases) and oxidative phosphorylation: cytochrome c oxidases and NADH dehydrogenases (Table 2). As illustrated In Figure 2c, the weighted pathway regulation (WPR) score revealed that these groups of genes were altered much more than the entire transcriptome. Remarkably, $A t p 1 b 2$, one of the major players responsible for establishing and maintaining the transmembrane electrochemical gradients of $\mathrm{Na}^{+}$and $\mathrm{K}^{+}$, was the most downregulated in all three PH models (-146× in $\mathrm{HO},-257 \times$ in $\mathrm{CM}$, and $-111 \times$ in $\mathrm{HM})$.

Table 2. Significantly up- (positive fold-change in bold numbers) and downregulated (negative fold-change in bold numbers) ATPases, cytochrome c oxidases, and NADH dehydrogenases in the three $\mathrm{PH}$ rat models. Note the range of the CUTs, from 1.24 (for the regulation of Ndufv3 in HM vs. CO) to 3.68 (for the regulation of Cox6a1 in $\mathrm{HO}$ vs. $\mathrm{CO}$ ). Our procedure to determine the cut-off for the absolute fold-change for every gene in each comparison instead of using a fixed cut-off (like 1.5 $\times$ ) eliminated the false regulations (expression ratio in Italics, e.g., Atp11b in $\mathrm{HO} / \mathrm{CO}$ ), whose absolute (although over $1.5 \times$ ) fold-change was below the CUT (2.28) computed for that gene in the compared conditions.

\begin{tabular}{|c|c|c|c|c|c|c|c|}
\hline Gene & Description & $\mathrm{HO} / \mathrm{CO}$ & CUT & $\mathrm{CM} / \mathrm{CO}$ & CUT & $\mathrm{HM} / \mathrm{CO}$ & CUT \\
\hline Atp11b & ATPase phospholipid transporting 11B & -1.74 & 2.28 & 1.34 & 2.46 & 2.05 & 1.82 \\
\hline Atp13a2 & ATPase type $13 \mathrm{~A} 2$ & -1.67 & 2.18 & 1.55 & 2.40 & 2.11 & 2.00 \\
\hline Atp1a1 & ATPase, $\mathrm{Na}+/ \mathrm{K}+$ transporting, $\alpha 1$ polypeptide & -1.78 & 3.34 & 4.01 & 3.08 & 6.65 & 2.25 \\
\hline Atp1a3 & ATPase, $\mathrm{Na}+/ \mathrm{K}+$ transporting, $\alpha 3$ polypeptide & -1.52 & 1.71 & -1.86 & 1.95 & -3.48 & 2.07 \\
\hline Atp1b2 & ATPase, $\mathrm{Na}+/ \mathrm{K}+$ transporting, $\beta 2$ polypeptide & -146.48 & 3.21 & -257.37 & 2.51 & -111.20 & 2.47 \\
\hline Atp1b3 & ATPase, $\mathrm{Na}+/ \mathrm{K}+$ transporting, $\beta 3$ polypeptide & 2.14 & 2.32 & 12.00 & 2.35 & 15.88 & 1.26 \\
\hline Atp2a2 & $\begin{array}{l}\text { ATPase, Ca++ transporting, cardiac muscle, slow } \\
\text { twitch } 2\end{array}$ & 1.56 & 2.48 & 4.83 & 2.46 & 10.66 & 1.49 \\
\hline Atp2a3 & ATPase, $\mathrm{Ca}++$ transporting, ubiquitous & 1.40 & 1.95 & 1.62 & 1.87 & 1.88 & 1.39 \\
\hline Atp2b1 & ATPase, $\mathrm{Ca}++$ transporting, plasma membrane 1 & -3.70 & 3.00 & -1.19 & 2.86 & 1.30 & 2.34 \\
\hline Atp $2 b 4$ & ATPase, $\mathrm{Ca}++$ transporting, plasma membrane 4 & -2.48 & 1.90 & -1.69 & 2.59 & -11.70 & 2.28 \\
\hline Atp2c1 & ATPase, $\mathrm{Ca}++$ transporting, type $2 \mathrm{C}$, member 1 & -1.35 & 1.67 & 1.24 & 1.69 & 1.85 & 1.50 \\
\hline Atp $4 a$ & ATPase, $\mathrm{H}+/ \mathrm{K}+$ exchanging, $\alpha$ polypeptide & 1.13 & 1.59 & -1.12 & 1.94 & -2.35 & 1.61 \\
\hline Atp5d & $\begin{array}{l}\text { ATP synthase, H+ transporting, mitochondrial F1 } \\
\text { complex, delta subunit }\end{array}$ & 2.27 & 3.21 & 6.84 & 2.82 & 9.15 & 1.92 \\
\hline Atp5f1 & $\begin{array}{l}\text { ATP synthase, } \mathrm{H}+\text { transporting, mitochondrial Fo } \\
\text { complex, subunit B1 }\end{array}$ & 4.36 & 3.01 & 27.45 & 2.92 & 51.30 & 1.67 \\
\hline
\end{tabular}


Table 2. Cont

\begin{tabular}{|c|c|c|c|c|c|c|c|}
\hline Gene & Description & $\mathrm{HO} / \mathrm{CO}$ & CUT & $\mathrm{CM} / \mathrm{CO}$ & CUT & $\mathrm{HM} / \mathrm{CO}$ & CUT \\
\hline Atp5g1 & $\begin{array}{l}\text { ATP synthase, } \mathrm{H}+\text { transporting, mitochondrial Fo } \\
\text { complex, subunit } \mathrm{C} 1\end{array}$ & 4.71 & 3.18 & 10.84 & 2.78 & 16.08 & 2.08 \\
\hline Atp5g2 & $\begin{array}{l}\text { ATP synthase, } \mathrm{H}+\text { transporting, mitochondrial Fo } \\
\text { complex, subunit } \mathrm{C} 2\end{array}$ & 3.21 & 2.91 & 14.44 & 2.84 & 26.97 & 1.86 \\
\hline Atp5g3 & ATP synthase membrane subunit c locus 3 & -7.56 & 3.23 & -1.08 & 3.22 & 1.35 & 2.35 \\
\hline Atp5i & $\begin{array}{l}\text { ATP synthase, } \mathrm{H}+\text { transporting, mitochondrial Fo } \\
\text { complex, subunit E }\end{array}$ & 17.18 & 2.97 & 11.45 & 2.89 & 15.65 & 2.19 \\
\hline Atp5j2 & $\begin{array}{l}\text { ATP synthase, } \mathrm{H}+\text { transporting, mitochondrial Fo } \\
\text { complex, subunit F2 }\end{array}$ & -1.27 & 2.91 & 5.30 & 2.90 & 8.37 & 2.24 \\
\hline Atp6r0a1 & $\begin{array}{c}\text { ATPase, } \mathrm{H}+\text { transporting, lysosomal V0 } \\
\text { subunit A1 }\end{array}$ & 4.14 & 2.57 & 3.11 & 2.35 & 4.83 & 1.65 \\
\hline Atp6v0a2 & $\begin{array}{c}\text { ATPase, } \mathrm{H}+\text { transporting, lysosomal V0 } \\
\text { subunit A2 }\end{array}$ & -2.76 & 2.21 & -2.35 & 2.37 & -1.52 & 2.16 \\
\hline Atp6r0b & ATPase, $\mathrm{H}+$ transporting, lysosomal V0 subunit B & -6.71 & 3.10 & -1.45 & 3.18 & -1.31 & 2.59 \\
\hline Atp6v0c & ATPase, $\mathrm{H}+$ transporting, lysosomal V0 subunit $\mathrm{C}$ & -31.61 & 2.78 & -5.37 & 3.13 & -3.65 & 2.39 \\
\hline Atp6r0e1 & $\begin{array}{c}\text { ATPase, } \mathrm{H}+\text { transporting, lysosomal, V0 } \\
\text { subunit e1 }\end{array}$ & 1.78 & 2.25 & 16.44 & 2.87 & 26.14 & 1.32 \\
\hline Atp6r0e2 & ATPase, $\mathrm{H}+$ transporting V0 subunit $\mathrm{e} 2$ & 1.84 & 2.59 & -3.40 & 1.79 & -5.62 & 1.95 \\
\hline Atp6v1f & ATPase, $\mathrm{H}$ transporting, lysosomal V1 subunit $\mathrm{F}$ & 1.10 & 2.22 & 5.42 & 2.78 & 9.44 & 1.53 \\
\hline Atp6v1g2 & $\begin{array}{c}\text { ATPase, } \mathrm{H}+\text { transporting, lysosomal V1 } \\
\text { subunit G2 }\end{array}$ & -11.80 & 2.62 & -16.92 & 2.68 & -39.54 & 2.66 \\
\hline$A t p 7 b$ & ATPase, $\mathrm{Cu}++$ transporting, $\beta$ polypeptide & -1.10 & 1.95 & -1.61 & 2.13 & -4.23 & 1.93 \\
\hline Atpif1 & ATPase inhibitory factor 1 & 1.06 & 3.10 & 5.02 & 3.13 & 8.16 & 2.21 \\
\hline Cox14 & cytochrome c oxidase assembly factor COX14 & -3.02 & 2.38 & 1.25 & 2.48 & 1.45 & 2.12 \\
\hline Cox17 & cytochrome c oxidase assembly homolog 17 & -1.43 & 3.42 & 2.09 & 3.07 & 3.01 & 2.28 \\
\hline Cox18 & cytochrome c oxidase assembly homolog 18 & -2.41 & 2.11 & -1.51 & 2.20 & -1.23 & 2.03 \\
\hline Cox4i1 & cytochrome c oxidase subunit IV isoform 1 & 11.99 & 2.91 & 30.01 & 2.81 & 52.39 & 1.89 \\
\hline Cox4i2 & cytochrome c oxidase subunit IV isoform 2 (lung) & -6.30 & 3.02 & -4.07 & 2.77 & -2.89 & 2.32 \\
\hline Cox $5 b$ & cytochrome $\mathrm{c}$ oxidase subunit $\mathrm{Vb}$ & -9.14 & 2.93 & -1.85 & 3.15 & -1.02 & 2.34 \\
\hline Cox6a1 & cytochrome c oxidase, subunit VIa, polypeptide 1 & -1.85 & 3.68 & 1.66 & 3.10 & 2.87 & 2.24 \\
\hline Cox6a2 & cytochrome c oxidase subunit VIa polypeptide 2 & 1.33 & 2.05 & 2.99 & 2.60 & 16.89 & 2.29 \\
\hline Cox6b1 & cytochrome c oxidase subunit 6B1 & 4.27 & 2.82 & -3.59 & 2.54 & -3.02 & 2.29 \\
\hline Cox6b2 & cytochrome c oxidase subunit VIb polypeptide 2 & -3.95 & 2.64 & -7.82 & 2.34 & -7.12 & 2.32 \\
\hline Cox6c & cytochrome $\mathrm{c}$ oxidase, subunit VIc & 4.56 & 3.49 & 11.35 & 2.92 & 18.57 & 2.02 \\
\hline Cox7a2 & cytochrome c oxidase subunit VIIa polypeptide 2 & 1.85 & 2.97 & 7.68 & 2.74 & 12.31 & 1.95 \\
\hline Cox $7 b$ & cytochrome c oxidase subunit VIIb & 1.50 & 2.03 & 6.58 & 2.77 & 11.58 & 1.79 \\
\hline Cox8a & cytochrome c oxidase subunit VIIIa & -4.07 & 3.07 & 1.27 & 3.18 & 2.50 & 2.33 \\
\hline Cox8b & cytochrome c oxidase, subunit VIIIb & 2.96 & 2.01 & 2.35 & 1.93 & 6.01 & 2.37 \\
\hline Coa5 & cytochrome $\mathrm{C}$ oxidase assembly factor 5 & -20.24 & 2.92 & -8.03 & 3.05 & -11.72 & 2.93 \\
\hline Ndufa10 & $\begin{array}{l}\text { NADH dehydrogenase (ubiquinone) } 1 \alpha \\
\text { subcomplex } 10\end{array}$ & 1.24 & 2.99 & 1.81 & 2.56 & 3.27 & 1.92 \\
\hline Ndufa11 & $\begin{array}{l}\text { NADH dehydrogenase (ubiquinone) } 1 \alpha \\
\text { subcomplex } 11\end{array}$ & -1.02 & 2.24 & 3.51 & 2.08 & 3.92 & 1.72 \\
\hline Ndufa13 & NADH:ubiquinone oxidoreductase subunit A13 & -2.20 & 3.07 & 3.05 & 3.10 & 5.35 & 2.18 \\
\hline Ndufa3 & $\begin{array}{l}\text { NADH dehydrogenase (ubiquinone) } 1 \alpha \\
\text { subcomplex, } 3\end{array}$ & -4.15 & 2.81 & -2.79 & 2.51 & -2.08 & 2.25 \\
\hline Ndufa6 & $\begin{array}{c}\text { NADH dehydrogenase (ubiquinone) } 1 \alpha \\
\text { subcomplex, } 6 \text { (B14) }\end{array}$ & 4.42 & 3.33 & 15.50 & 2.84 & 28.28 & 1.71 \\
\hline Ndufaf5 & $\begin{array}{c}\text { NADH dehydrogenase (ubiquinone) complex I, } \\
\text { assembly factor } 5\end{array}$ & -1.16 & 2.21 & 1.50 & 2.45 & 2.21 & 1.94 \\
\hline Ndufb10 & $\begin{array}{l}\text { NADH dehydrogenase (ubiquinone) } 1 \beta \\
\text { subcomplex, } 10\end{array}$ & 2.67 & 3.13 & 4.78 & 2.67 & 7.57 & 1.63 \\
\hline$N d u f b 2$ & $\begin{array}{l}\text { NADH dehydrogenase (ubiquinone) } 1 \beta \\
\text { subcomplex, } 2\end{array}$ & 7.38 & 3.22 & 20.76 & 2.78 & 35.55 & 1.73 \\
\hline
\end{tabular}


Table 2. Cont.

\begin{tabular}{|c|c|c|c|c|c|c|c|}
\hline Gene & Description & $\mathrm{HO} / \mathrm{CO}$ & CUT & $\mathrm{CM} / \mathrm{CO}$ & CUT & $\mathrm{HM} / \mathrm{CO}$ & CUT \\
\hline$N d u f b 3$ & $\begin{array}{l}\text { NADH dehydrogenase (ubiquinone) } 1 \beta \\
\text { subcomplex } 3\end{array}$ & 3.15 & 2.92 & 7.29 & 2.42 & 12.14 & 1.60 \\
\hline$N d u f b 4$ & $\begin{array}{l}\text { NADH dehydrogenase (ubiquinone) } 1 \beta \\
\text { subcomplex } 4\end{array}$ & 3.52 & 3.35 & 11.33 & 2.85 & 21.34 & 1.89 \\
\hline Ndufb5 & $\begin{array}{l}\text { NADH dehydrogenase (ubiquinone) } 1 \beta \\
\text { subcomplex, } 5\end{array}$ & 1.31 & 2.83 & 4.31 & 2.77 & 6.50 & 1.94 \\
\hline$N d u f b 6$ & $\begin{array}{l}\text { NADH dehydrogenase (ubiquinone) } 1 \beta \\
\text { subcomplex, } 6\end{array}$ & -6.75 & 2.75 & -1.20 & 3.14 & 1.33 & 2.28 \\
\hline$N d u f b 7$ & $\begin{array}{l}\text { NADH dehydrogenase (ubiquinone) } 1 \beta \\
\text { subcomplex, } 7\end{array}$ & -4.28 & 3.63 & -1.59 & 3.12 & -1.12 & 2.32 \\
\hline$N d u f b 8$ & $\begin{array}{l}\text { NADH dehydrogenase (ubiquinone) } 1 \beta \\
\text { subcomplex } 8\end{array}$ & 2.64 & 3.37 & 7.96 & 3.09 & 13.61 & 2.35 \\
\hline$N d u f b 9$ & $\begin{array}{l}\text { NADH dehydrogenase (ubiquinone) } 1 \beta \\
\text { subcomplex, } 9\end{array}$ & 1.67 & 2.89 & 11.81 & 2.95 & 19.58 & 2.16 \\
\hline$N d u f s 3$ & $\begin{array}{l}\text { NADH dehydrogenase (ubiquinone) Fe-S } \\
\text { protein } 3\end{array}$ & -5.54 & 3.14 & -1.39 & 3.14 & 1.08 & 2.42 \\
\hline$N d u f_{s} 5$ & $\begin{array}{l}\text { NADH dehydrogenase (ubiquinone) Fe-S } \\
\text { protein } 5\end{array}$ & 3.54 & 2.87 & 12.91 & 2.84 & 23.34 & 1.94 \\
\hline$N d u f_{s} 7$ & $\begin{array}{l}\text { NADH dehydrogenase (ubiquinone) Fe-S } \\
\text { protein } 7\end{array}$ & 5.04 & 3.35 & 8.90 & 2.68 & 10.68 & 1.74 \\
\hline Ndufv1 & $\begin{array}{l}\text { NADH dehydrogenase (ubiquinone) } \\
\text { flavoprotein } 1\end{array}$ & 5.55 & 3.38 & 8.51 & 2.82 & 14.54 & 1.94 \\
\hline Ndufv3 & $\begin{array}{l}\text { NADH dehydrogenase (ubiquinone) } \\
\text { flavoprotein } 3\end{array}$ & 1.32 & 1.95 & 2.12 & 2.22 & 3.71 & 1.24 \\
\hline Sdhaf2 & $\begin{array}{l}\text { succinate dehydrogenase complex assembly } \\
\text { factor } 2\end{array}$ & 2.15 & 2.69 & 4.59 & 2.76 & 7.66 & 1.73 \\
\hline
\end{tabular}

Alteration of the genes encoding mitochondrial ribosomal proteins is also presented for comparison in the Supplementary Table S2.

3.10. Remodeling of the Relationship between the Genes Involved in the Vascular Smooth Muscle Contraction and Oxidative Phosphorylation

We studied how much the interaction of the vascular smooth muscle contraction genes (VSMC, rno04270) (presented in Figure 3) with genes involved in oxidative phosphorylation (OP), particularly with ATPases, is remodeled by pulmonary hypertension. For this, we computed the Pearson correlation coefficients for the 1248 pairs that can be formed with the 32 ATPases and 39 VSMC genes adequately quantified in each of the four experimental conditions. Interestingly, we found that each $\mathrm{PH}$ condition significantly reduced the net positive correlation (i.e., number of positively $(\mathrm{p})$ - number of negatively (n) correlated gene-pairs): from $450(=472 p-22 n)$ in CO to $236(=280 p-44 n)$ in HO, $340(=455 p-115 n)$ in CM and 208 (= 262p - 54n) in HM. Figure 5 presents the significantly synergistically, antagonistically, and independently expressed pairs of VSMC genes with ATPases in CO, and the pairs whose expression correlation was significantly altered in the three $\mathrm{PH}$ models. Interestingly, the negative correlation of Rhoa with 15 ATPases (Atp11b, Atp13a2, Atp1a1, Atp1a3, Atp2a3, Atp2b1, Atp2c1, Atp4a, Atp5e, Atp5g3, Atp6v0a2, Atp6v0b, Atp6v0c, Atp6v0e1, Atp6v1g2) and no positive correlation in control rats was cancelled in the PH models, with several correlations even reversed. 
(a)

(b)

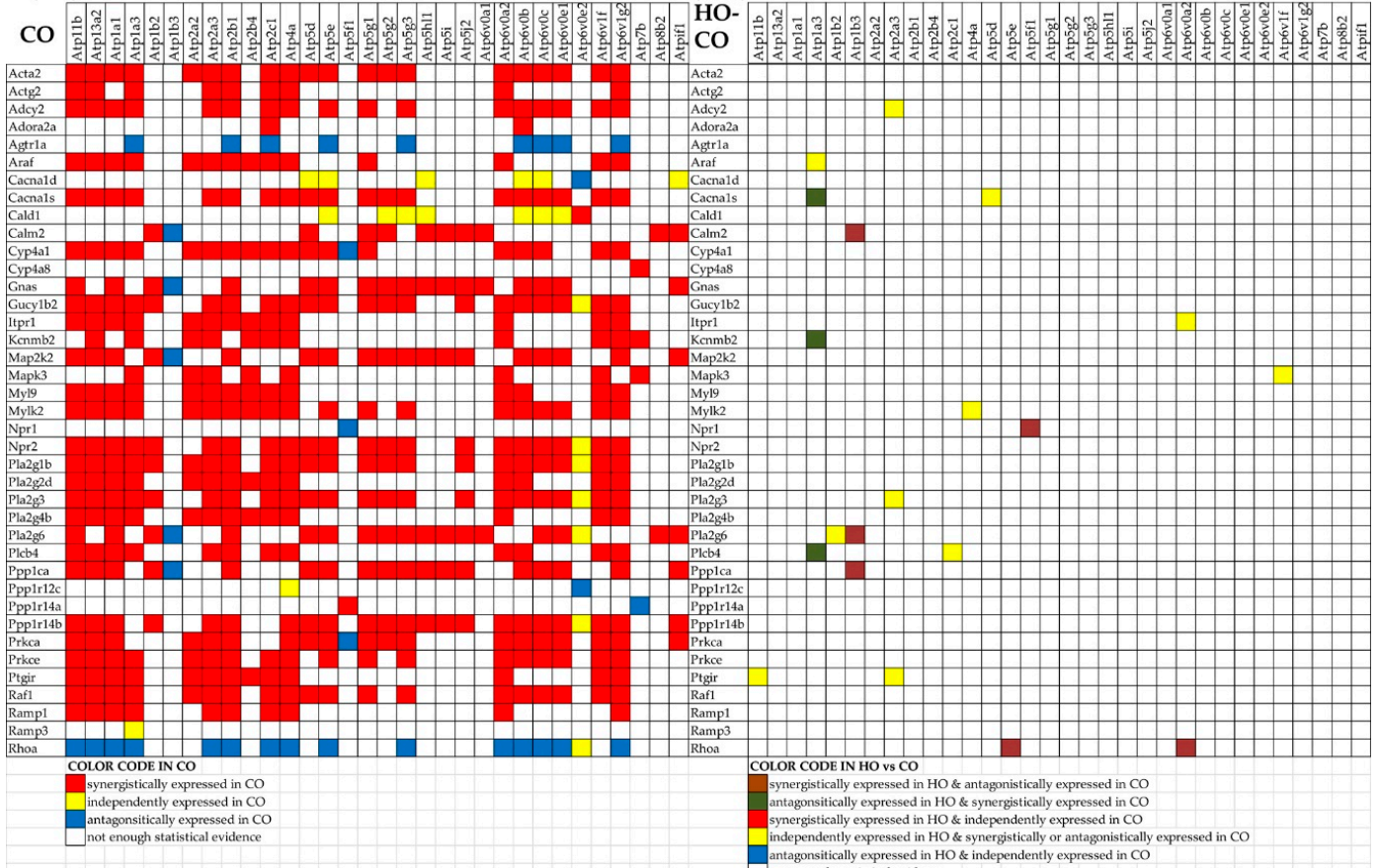

(c)

(d)

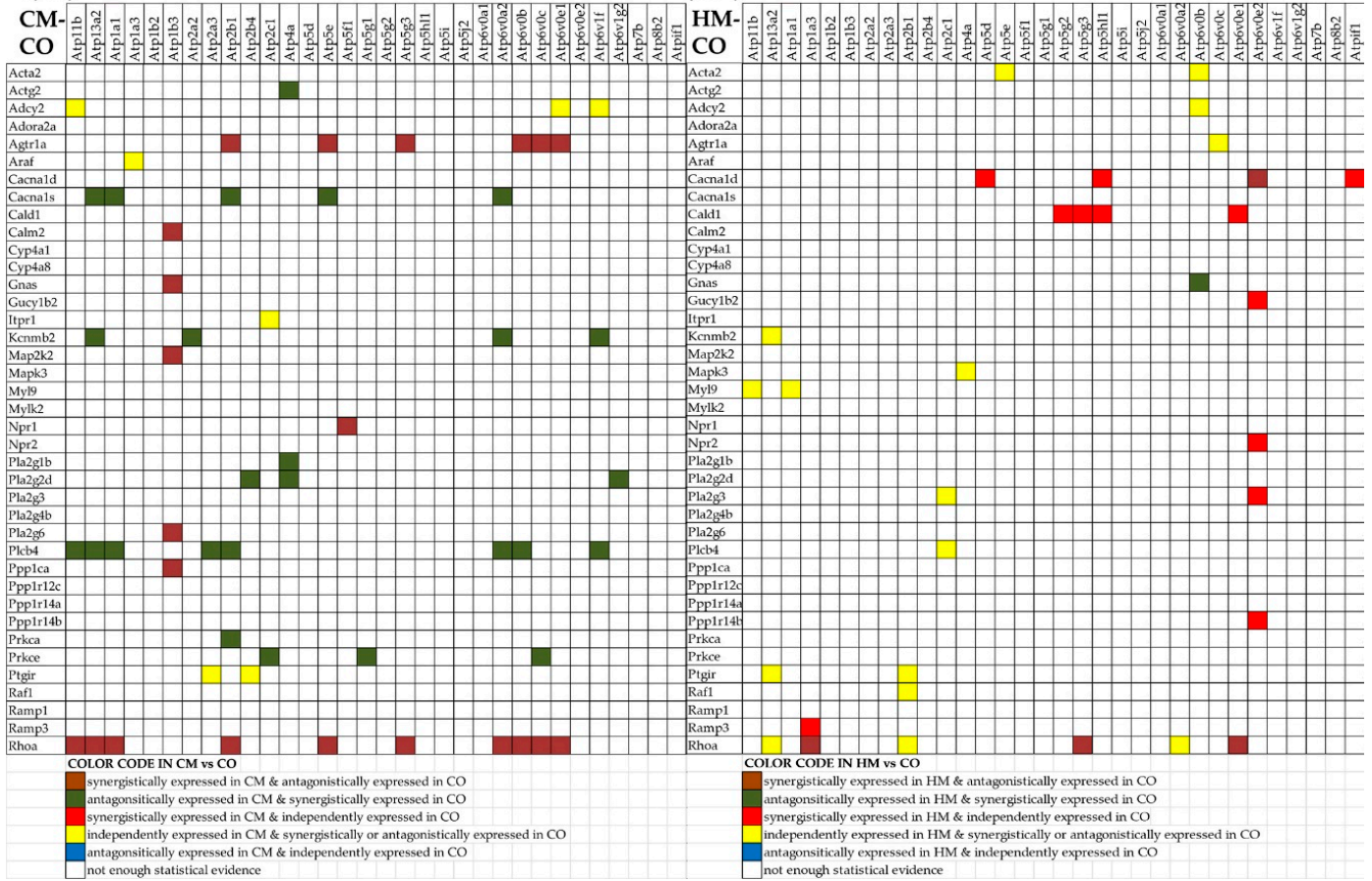

Figure 5. Synergistically (red squares), antagonistically (blue squares), and independently (yellow squares) expressed pairs of VSMC genes and ATPases in CO (a) whose expression correlation was significantly altered by hypoxia (b), monocrotaline (c), or the combined action of hypoxia and monocrotaline (d). A blank square in (a) indicates that the correlation is not $(p<0.05)$ statistically significant. 
We then used the new measure gene pair prominence (GPP, Equation (4)) to rank the gene pairs of the interplay between the two groups of genes. The positive and negative GPPs were plotted separately (as $\mathrm{CO}+$ and $\mathrm{CO}-, \mathrm{HO}+$ and $\mathrm{HO}-, \mathrm{CM}+$ and $\mathrm{CM}-, \mathrm{HM}+$ and $\mathrm{HM}-$ ) to emphasize the type and importance of their expression correlation. The GPPs of all genes in each condition were expressed as the percentage of the maximal absolute GPP in that condition, regardless of whether it was positive or negative. Except for the CM condition, where the genes of the dominant pair (Cyp4a8-Atp5e) were negatively correlated, the positively correlated pairs had much larger GPPs than the negatively correlated ones, meaning that expression of most ATPases oscillates in phase with most VSMC genes.

The analysis pointed out three remarkable $\mathrm{H}^{+}$transporters (Atp5e, Atp6v0a2, Atp6v0e2) in strong partnership with three VSMC genes: Cyp4a8 (cytochrome P450 family 4, subfamily a, polypeptide 8), Gnas (GNAS complex locus), and Mapk3 (mitogen-activated protein kinase 3). Mapk3, involved in a wide range of pathways (listed in [51]), provides the most prominent positive pairs with Atp6v0a2 in normal atmospheric conditions and with Atp6v0e2 in hypoxia (obtained by reducing the atmospheric pressure in half).

\section{Discussion}

We examined the transcriptomic alterations in the right lungs of male rats with pulmonary hypertension induced by exposure to hypoxia (HO group), administration of monocrotaline (CM group), or exposure to hypoxia of monocrotaline-treated animals (HM group). There are numerous common features of the three experimental groups, making them valuable models for the human pulmonary hypertension, including lower weight gain but right-ventricle hypertrophy and increased right-ventricle systolic pressure. However, there are also significant differences as revealed by the present and previous studies.

At four weeks after hypobaric hypoxia, there is significant PH and RVH. The hypoxia-induced $\mathrm{PH}$ in rats is not associated with any disruption of EC, loss of endothelial Cav1 or Nos3, or enhanced expression of Cav1 in VSMC. Despite the presence of endothelial Cav1 protein, pro-proliferative and anti-apoptotic pathways are activated, indicating Cav1 dysfunction [30,52]. In addition, the lung sections from infants with respiratory distress syndrome show that the presence of increased pulmonary artery pressure unaccompanied by endothelial damage does not result in the loss of endothelial CAV1 or enhanced expression of CAV1 in VSMC [29].

In the CM model, the loss of endothelial Cav1 is accompanied by the loss of endothelial proteins such as Pecam1 and soluble guanylate cyclase, and the activation of pro-proliferative and anti-apoptotic pathways leading to $\mathrm{PH}$. At two weeks post monocrotaline administration, progressive loss of endothelial Cav1 is associated with $\mathrm{PH}$ and $\mathrm{RVH}$ in rats $[12,40]$. As the disease progresses, a further loss of endothelial Cav1 is accompanied by a loss of von Willebrand factor (vWF), indicative of extensive endothelial damage. Importantly, some of the arteries with vWF loss start to exhibit enhanced expression of CAV1 in VSMC, accompanied by increased Mmp2 expression and activity [51]. At four weeks, the significant loss of endothelial Cav1 is accompanied by enhanced expression of Cav1 in VSMC. The total Cav1 expression in the lungs increases by $39.14 \times$ compared to controls.

Exposing monocrotaline-treated rats to hypoxia (HM group) accelerates the disease process, resulting in significantly higher RVSP and RVH, extensive EC damage, and endothelial Cav1 loss, accompanied by enhanced expression of Cav1 in VSMC and neointima lesions [36,53,54]. Furthermore, $61 \%$ of the arteries exhibited enhanced expression of Cav1 in VSMC; Cav1 expression in the lungs increased to $81 \%$ of the controls. However, the neointimal lesions in the HM group exhibited loss of Cav1 and normal Nos3 expression. In the absence of Cav1, Nos3 gets uncoupled and produces nitrosative and oxidative stress. Cav1 expression is significantly increased $(79.06 \times)$. It is worthy of note here that the neointimal cells have low Cav1 and near normal Nos3 expression, which is a set-up for oxidative and nitrosative stress. These results strongly support a dual role of Cav1 in the pathogenesis and the progression of $\mathrm{PH}$, similar to what was reported in cancer $[55,56]$. 
We found that Mmp2 was overexpressed by $9.14 \times$ in $\mathrm{HO}$, by $39.59 \times$ in $\mathrm{CM}$, and by $81.47 \times$ in HM. MMP2 is known to degrade extracellular matrix and facilitate cell proliferation and migration. Increased $M M P 2$ expression activity was reported in human PAH [57,58] and in monocrotaline-induced $\mathrm{PH}$ in rats [53].

Many of the upregulated inflammatory genes from Table 1 were also reported by other authors as related to PH. For instance, Ccl5 (also known as RANTES; 4.56× in CM and 4.40× in HM), an important chemoattractant for monocytes and T cells, was shown to be increased in PAH [59]. Interestingly, deletion of Ccl5 was shown to attenuate the Sugen-hypoxia model of PH via Cav1-dependent amplification of Bmpr2 signaling [60]. As presented in Figure 2d, we found Bmpr2 as upregulated by $1.78 \times$ in $\mathrm{HM}$, but it stayed practically unchanged in $\mathrm{HO}$ and $\mathrm{CM}$.

Increased expression of CXCR4, a receptor for the chemokine stromal cell-derived factor 1 (SDF1), was reported in the lungs of patients with IPAH, HPAH, and PAH associated with congenital heart defect [61]. Increased Cxcr4 was also reported in Sugen + hypoxia and monocrotaline + hypoxia rodent models of PH [62]. Inhibition of Cxcr4 moderately attenuated pulmonary vascular remodeling in the Sugen + hypoxia model [63], while overexpression of Cxcr4 participates in the repair of tissue injury [64]. In the present study (Table S1), Cxcr4 was found to be upregulated in CM (4.56×) and HM (2.84×). The lower amplification in HM as compared to CM may be explained by the (even not statistically significant) negative effect of hypoxia $(-1.21 \times$ in $\mathrm{HO})$. Of note is the upregulation of the tumor necrosis factors and their receptors, confirming the upstream regulator role of the TNF [1].

Ciapin1 (upregulated by $3.16 \times$ in CM and by 5.16× in HM, Table S1) promotes anti-apoptosis and cell proliferation via the cyclins D1 (Ccnd1) and E1 (Ccne1), and cyclin-dependent kinases (Cdk) 2 and 4 [65]. Our study confirmed the upregulation for Ccnd1 (1.93× in HM) and Cdk4 $(1.49 \times$ in HO, 4.26× in $\mathrm{CM}$, and $5.31 \times$ in $\mathrm{HM})$. Yet, we found $C d k 2$ as not regulated and Ccne1 as downregulated $(-2.78 \times$ in $\mathrm{HO})$. Interestingly, in human VSMC cell culture, CIAPIN1 siRNA was shown to inhibit cell proliferation and enhance apoptosis by increasing Bcl2 and Bax [66]. These results in cell culture suggest that upregulation of Ciapin1 should correlate with downregulation of $B c l 2$ and Bax. Indeed, we found $B c l 2$ as downregulated ( $-2.47 \times$ in HM), but Bax was found as upregulated $(2.59 \times$ in CM and 2.69× in HM). However, the upregulation of Bax is not necessarily a contradiction because Ciapin1 knockdown by siRNA and its upregulation by MCT are triggered by different mechanisms and, hence, not symmetrical phenomena, involving the opposite regulation of the same set of genes. Moreover, as we proved for oligodendrocytes [67] and neurons [68], the heterogeneous cellular environment and external stimuli (missing in the VSMC monoculture but present in the lung) are potent transcriptome modulators.

Among others, we found that $N f k b 1$ (nuclear factor kappa B subunit 1), one of the controllers of the cytokine production, was upregulated by $3.50 \times$ in CM and by $3 \times$ in HM (Figure 1d). Icam1 (intercellular adhesion molecule 1) was significantly upregulated by $6.79 \times$ in $\mathrm{HO}, 23.65 \times$ in $\mathrm{CM}$, and $43.97 \times$ in $\mathrm{HM}$, while Vcam1 (vascular cell adhesion molecule 1) was upregulated by $2.12 \times$ in $\mathrm{HO}$, by $6.46 \times$ in $\mathrm{CM}$, and by $11.25 \times$ in HM. Lgals3 (galectin3), with a critical role in vascular inflammation and fibrosis and heart failure, was also found as upregulated by 10.89× in CM and 17.83× in HM. Importantly, increased expression of Lgals3 and Icam1 was shown to be present in patients with IPAH and connective tissue disease [69].

Anxa 1 (annexin A1, increased by 9.64× in HO, 56.48× in CM, and 106.00× in HM) plays an essential role in cell invasion and migration [70]. It is also an anti-inflammatory protein that controls pro-inflammatory mediator release. It promotes leukocyte detachment from EC and serves as a negative regulator of the transmigratory processes [71,72], and it provides protection from neointima formation in atherosclerosis [73]. Eng (endoglin, 3.03× in CM and 9.00x in HM), a transmembrane receptor for TGF $\beta$ signaling, plays a key role in the balance of Alk1 and Alk5 signaling that regulates EC proliferation. Increased expression of Alk1/Eng was reported in EC in IPAH. Furthermore, endoglin deficiency protects mice from hypoxic PH [74]. Nfat5 (nuclear factor activated T cells 5; 3.59× in HM), is implicated in the regulation of genes associated with migration and proliferation $[75,76]$. Our genomic analysis also revealed increased expression of $E d n 1$ (endothelin 1, 1.88× in HO, 1.83× in CM, and 3.11× 
in HM), Myc (myelocytomatosis oncogene, $5.92 \times$ in CM and $6.42 \times$ in HM), $P d g f a$ (platelet-derived growth factor $\alpha, 2.77 \times$ in $\mathrm{HO}, 4.63 \times$ in $\mathrm{CM}$, and $6.39 \times$ in $\mathrm{HM}$ ).

The complementary effects of the administration of monocrotaline and exposure to hypoxia are perfectly illustrated by the regulation of the six quantified cyclin-dependent kinases, the key regulatory enzymes of the cell cycle. Thus, $C d k n 2 a$ was downregulated in $\mathrm{HO}$ and HM groups but not affected in $\mathrm{CM}$, while $C d k n 1 a$ was downregulated and $C d k n 1 b, C d k n 1 c$, and $C d k n 2 b$ were upregulated in $\mathrm{CM}$ and $\mathrm{HM}$ groups but not in the HO group. Cyclin-dependent kinases are among the targeted genes for the treatment of pulmonary arterial hypertension [77].

As illustrated in panels (d), (e), and (f) in both Figure 3 (VSMC pathway) and Figure 4 (CC pathway), we found significant correlations between the gene expression regulations in the three models. However, the correlation between the regulations in HM and CM models was much stronger than between $\mathrm{CM}$ and $\mathrm{HO}$ or between $\mathrm{HM}$ and $\mathrm{HO}$. We found 23 genes (Figure 2e) whose regulation in $\mathrm{HO}$ was opposite to regulation in both $\mathrm{CM}$ and $\mathrm{HM}$, and only one gene (Plcb4) whose regulation in $\mathrm{HM}$ was opposite to regulation in both CM and HM. Since the HM rats were exposed to both hypoxia and MCT treatment, each upregulating Plcb4, the downregulation of this phospholipase C in HM is surprising and deserves further study.

Mitochondria are the major sources of reactive oxygen species (ROS) and highly susceptible to oxidative stress. Increased ROS production and mitochondrial dysfunction occur in a number of diseases including cardiovascular diseases. A significant increase (3.46×) in the expression of Parp1 (poly (ADP-ribose) polymerase-1) was found in the lungs of rats exposed to both MCT and hypoxia (HM group). Most of the activity of Parp1 is localized in the nucleus. Recent studies showed DNA damage and associated increased expression of Pparp1 to be important aspects of human PAH. Parp1 is implicated in DNA repair, allowing cell proliferation during stress. Parp1 plays an important role in cellular functions during health and disease [78]. Although, in humans, PARP1 was reported to upregulate HIF1A, IL6, and NFAT5 [79,80], we found only Nfat5 as upregulated (see above). Hif1 $\alpha$ was downregulated by $-1.72 \times$ in $\mathrm{HO}$, by $-2.04 \times$ in $\mathrm{CM}$, and by $-1.59 \times$ in $\mathrm{HM}$, and $I l 6$ was downregulated by $-3.18 \times$ in HM.

Upregulation of other important genes includes Slc2a1 (solute carrier family 2 (facilitated glucose transporter), member $1 ; 2.94 \times$ in $\mathrm{HM}$ ), Sod2 (mitochondrial superoxide dismutase; $2.23 \times$ in $\mathrm{HM}$ ), Hmox1 (hemoxygenase 1; 4.53× in CM and 9.11x in HM), Gpx1 (glutathione peroxidase 1; 20.48× in HO, $84.91 \times$ in $\mathrm{CM}$, and 116.90× in HM), Txn1 (thioredoxin; 7.09× in HO, 54.27× in CM, and 93.90× in HM), $\mathrm{Nfe} 2 l 2$ (nuclear factor (erythroid-derived-2)-like-2; 3.13× in CM and 5.97× in HM), Mfn2 (mitofusin 2; $2.69 \times$ in $\mathrm{HM}$ ), and Nq01 (NAD (P) dehydrogenase quinone 1; 3.50× in CM and 3.97× in HM). Idh2 (isocitrate dehydrogenase; $4.33 \times$ in $\mathrm{HO}, 16.08 \times$ in $\mathrm{CM}$, and $28.92 \times$ in $\mathrm{HM}$ ) is an NADPH-generating enzyme that plays an important role in regulating mitochondrial redox balance and diminishing stress-induced injury [81]. Low Mfn leads to attenuated angiogenic response to VEGF and eNOS [82].

Recent studies in PAH revealed a metabolic shift toward aerobic glycolysis ("Warburg effect") similar to what was observed in cancer, utilized by proliferating cells for survival. Cav1 was shown to stabilize mitochondria, prevent aerobic glycolysis [35], and negatively regulate NADPH-derived reactive oxygen species [82]. Furthermore, Cav1 modulates Nrf2 expression [83]. It is an important observation that neointimal cells have low Cav1 and normal eNOS expression, resulting in oxidative and nitrosative stress [30]. Compared with the HO group, in the CM and HM groups, there was significantly increased expression of several antioxidants, such as Nfe2l2, $\operatorname{Prdx2}$ (peroxiredoxin 2; 2.66× in $\mathrm{HO}, 33.94 \times$ in $\mathrm{CM}$, and 46.01× in HM), Gpx1, Gpx2 (4.92× in HO, 23.70× in CM, and 24.47× in HM), Txn1, Sod2, Hmox1, and Nqo1. These alterations provide an anti-oxidative and glycolytic milieu for the survival of the proliferating cells.

The analysis of the expression coordination between respiratory and VSMC genes (Figure 5) revealed several interesting interactions. For instance, in $\mathrm{CO}$, Rhoa has no positive partners but has 15 negative partners and one independent partner (i.e., 0/15/1) among the 32 ATPases, with its coordination power being $\mathrm{CP}=-74.47 \%$. The situation is reversed in all the three PH models: nine 
positives, no negatives, no independents (9/0/0) with a CP of $+61.07 \%$ in $\mathrm{HO}, 23 / 0 / 1$, a CP of +66.37 in $\mathrm{CM}, 6 / 0 / 3$, and a CP of +63.93 in HM. Importantly, 10 of the positively correlated ATPase partners of $R$ hoa in CM were negative partners in CO. This switch from negative to positive correlation of $R$ hoa with the ATPases justifies the reported "role of the Nox4-derived ROS-mediated RhoA/Rho kinase pathway in rat hypertension induced by chronic intermittent hypoxia" [84]. Confirming other reports of increased Rhoa in PH [83], we found Rhoa as upregulated by 7.00× in HO, 6.78× in CM, and 9.21× in HM. Our results complete the results of a previous report [85] by showing that Rhoa is upregulated and plays an important role regardless of what caused the PH. Moreover, we found also that Rhoa's action is mediated by the ATPases, a result that needs further investigation, especially in the light of the recent discovery of pathogenic mutations of the (not quantified in our study) ATP13A3 gene in IPAH [86].

The gene pair prominence (GPP) analysis demonstrated the plasticity of the genomic fabrics and their interplay. Figure 6 illustrates how the GPP landscape of the interaction between the vascular smooth muscle contraction (VSMC) genes and the ATPases is remodeled in the three PH conditions with respect to control. Interestingly, while, in control, a few VSMC genes interact with almost all ATPases, in all three PH models, almost all VSMC genes interact with a few ATPases, making the vascular smooth muscle contraction more vulnerable to certain point alteration within the respiratory chain. This new type of analysis can be used to identify the most important gene pairs in specific interactions. 


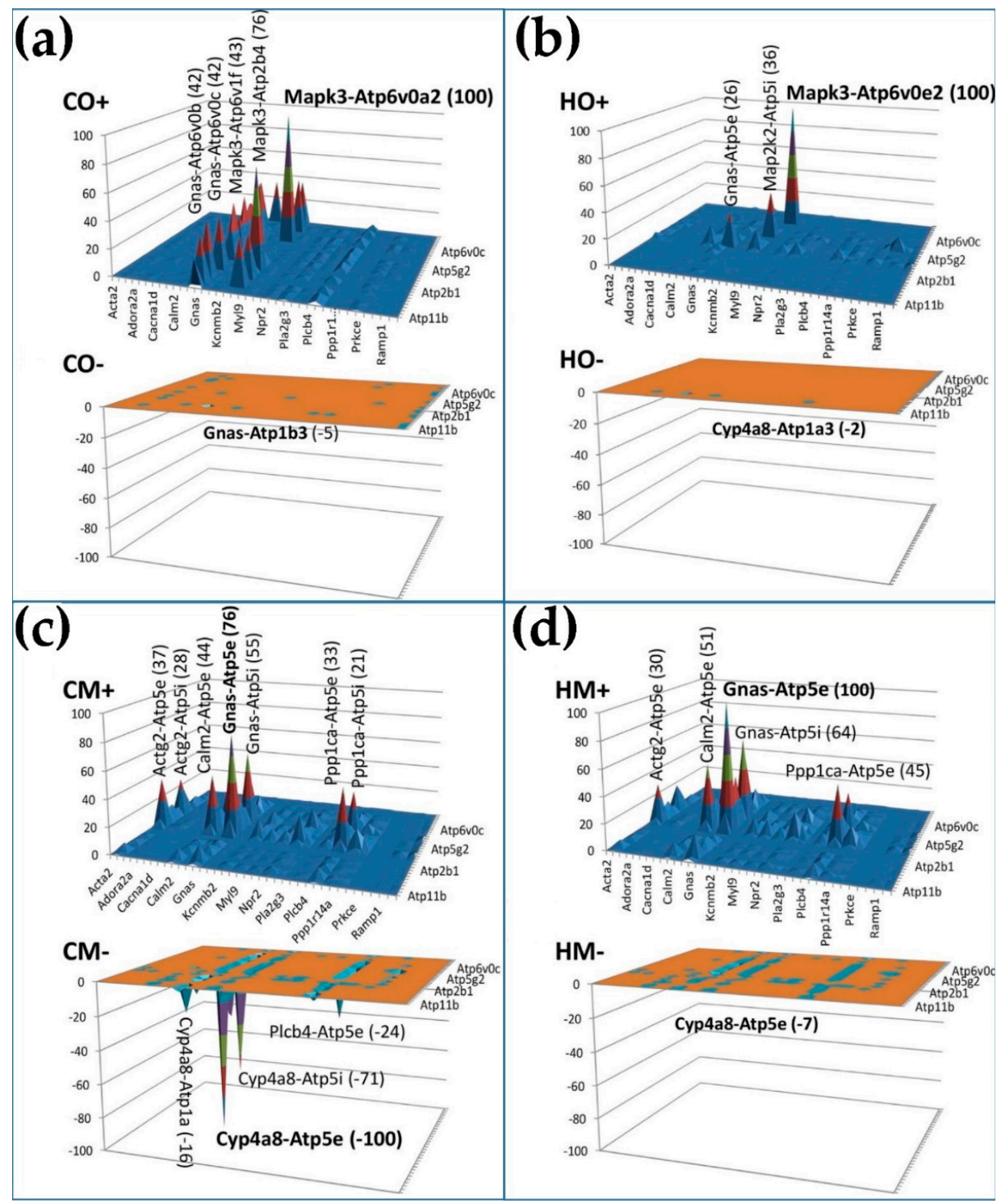

Figure 6. Gene pair prominence (GPP) analysis of the interaction of vascular smooth muscle contraction genes with the ATPases in the four conditions. (a) GPP values for the 472 positively $(\rho>0.9)$ and 36 negatively $(\rho<-0.9)$ correlated gene pairs in CO; (b) GPP values for the 280 positively and four negatively correlated gene pairs in HO; (c) GPP values for the 455 positively and 115 negatively correlated gene-pairs in CM; (d) GPP values for the 262 positively and four negatively correlated gene-pairs in HM.

\section{Conclusions}

All PH groups exhibited abnormal expression of genes involved in inflammation, cell proliferation, and vascular smooth muscle contraction. Importantly, monocrotaline-treated rats that were exposed to hypoxia, which shows similar changes to PAH, displayed evidence of mitochondrial damage and activation of antioxidants, which are likely to cause metabolic switch and provide a survival milieu for the proliferating cells. Our finding of the reversed correlation of Rhoa with ATPases from negative in control rats to positive in $\mathrm{PH}$ suggests a potential therapeutic avenue by targeting Rhoa and/or its partners, as suggested in 2008 [87]. 
Supplementary Materials: The following are available online at http://www.mdpi.com/2073-4425/11/2/126/s1: Table S1: Regulation of important genes involved in the immune-inflammatory response; Table S2: Regulation of mitochondrial genes.

Author Contributions: Conceptualization, R.M. and D.A.I.; methodology, R.M., S.I., and D.A.I.; software, D.A.I.; validation, R.M. and S.I.; formal analysis, S.I. and D.A.I.; investigation, J.H. and S.I.; resources, R.M. and D.A.I.; data curation, D.A.I., and R.M.; writing, D.A.I. and R.M.; visualization, D.A.I. and R.M.; supervision, R.M. and D.A.I.; project administration, R.M. and D.A.I.; funding acquisition, R.M. and D.A.I. All authors have read and agreed to the published version of the manuscript.

Funding: R.M., J.H., and S.I. were supported by an NYMC intramural grant. D.A.I. was supported by the Chancellor's Research Initiative (CRI) funding for the Center for Computational Systems Biology at the Prairie View A\&M University.

Conflicts of Interest: The authors declare no conflict of interest

\section{References}

1. Stearman, R.S.; Bui, Q.M.; Speyer, G.; Handen, A.; Cornelius, A.R.; Graham, B.B.; Geraci, M.W. Systems Analysis of the Human Pulmonary Arterial Hypertension Lung Transcriptome. Am. J. Respir. Cell Mol. Biol. 2019, 60, 637-649. [CrossRef]

2. Galiè, N.; McLaughlin, V.V.; Rubin, L.J.; Simonneau, G. An overview of the 6th World Symposium on Pulmonary Hypertension. Eur. Respir. J. 2019, 53, 1802148. [CrossRef]

3. D'Alonzo, G.C.; Barst, R.J.; Ayers, S.M.; Bergofsky, E.H.; Brundage, B.H.; Detre, K.M.; Levy, P.S. Survival in patients with primary pulmonary hypertension: Results from a national registry. Ann. Intern. Med. 1991, 115, 343-349. [CrossRef]

4. Pogoriler, J.E.; Rich, S.; Archer, S.L.; Husain, A.N. Persistence of complex vascular lesions despite prolonged prostacyclin therapy of pulmonary arterial hypertension. Histopathology 2012, 61, 597-609. [CrossRef]

5. Sakao, S.; Tatsumi, K.; Voelkel, N.F. Reversible or irreversible remodeling in pulmonary arterial hypertension. Am. J. Respir. Cell Mol. Biol. 2010, 43, 629-634. [CrossRef]

6. Humbert, M.; Sitbon, O.; Yaïci, A.; Montani, D.; O'Callaghan, D.S.; Jaïs, X.; Chaouat, A. Survival in incident and prevalent cohorts of patients with pulmonary arterial hypertension. Eur. Respir. J. 2010, 36, 549-555. [CrossRef]

7. Farber, H.W.; Miller, D.P.; Poms, A.D.; Badesch, D.B.; Frost, A.E.; Muros-Le Rouzic, E.; Benza, R.L. Five-Year outcomes of patients enrolled in the REVEAL Registry. Chest 2015, 148, 1043-1054. [CrossRef]

8. Deng, Z.; Morse, J.H.; Slager, S.L.; Cuervo, N.; Moore, K.J.; Venetos, G.; Hodge, S.E. Familial primary pulmonary hypertension (gene PPH1) is caused by mutations in the bone morphogenetic protein receptor-II gene. Am. J. Hum. Genet. 2000, 67, 737-744. [CrossRef]

9. Girerd, B.; Montani, M.; Coulet, F.; Sztrymf, B.; Yaici, A.; Jaïs, X.; Sitbon, O. Clinical Outcomes of Pulmonary Arterial Hypertension in Patients Carrying an ACVRL1 (ALK1) Mutation. Am. J. Respir. Crit. Care Med. 2010, 181, 851-861. [CrossRef]

10. Chaouat, A.; Coulet, F.; Favre, C.; Simonneau, G.; Weitzenblum, E.; Soubrier, F.; Humbert, M. Endoglin germline mutation in a patient with hereditary haemorrhagic tlangiectasia and dexfenfluramine associated pulmonary arterial hypertension. Thorax 2004, 59, 446-448. [CrossRef]

11. Drake, K.M.; Zygmunt, D.; Mavrakis, L.; Harbor, P.; Wang, L.; Comhair, S.A. Altered microRNA processing in heritable pulmonary arterial hypertension: An important role for Smad-8. Am. J. Respir. Crit. Care Med. 2011, 184, 1400-1408. [CrossRef]

12. Austin, E.D.; Ma, L.; LeDuc, C.; Berman-Rozenzweig, E.; Borczuk, A.; Phillips, J.A.; West, J. Whole exon sequence to identify a novel gene (caveolin-1) associated with human pulmonary arterial hypertension. Circ. Cardiovasc. Genet. 2012, 5, 336-343. [CrossRef]

13. Tejedor, P.N.; Castaño, J.T.; Doza, J.P.; Lajara, A.; Trujillo, G.G.; Meseguer, M.L.; Escribano Subía, P. A homozygous mutation in $\mathrm{KCNK} 3$ is associated with an aggressive form of hereditary pulmonary arterial hypertension. Clin. Genet. 2017, 91, 453-457. [CrossRef]

14. Eichstaedt, C.A.; Song, J.; Benjamin, N.; Harutyunova, S.; Fischer, C.; Grünig, E.; Hinderhofer, K. EIF2AK4 Mutation as "Second Hit" in Hereditary Pulmonary Arterial Hypertension. Respir. Res. 2016, 17, 141. [CrossRef] 
15. Aldred, M.A.; Comhair, S.A.; Varella-Garcia, M.; Asosingh, K.; Xu, W.; Noon, G.P.; Coldren, C.D. Somatic chromosome abnormalities in the lungs of patients with pulmonary arterial hypertension. Am. J. Respir. Crit. Care Med. 2010, 182, 1153-1160. [CrossRef]

16. Evans, J.D.; Girerd, B.; Montani, D.; Wang, X.-J.; Galiè, N.; Austin, E.D.; Jing, Z.C. BMPR2 mutations and survival in pulmonary arterial hypertension: An individual participant data meta-analysis. Lancet Respir. Med. 2016, 4, 129-137. [CrossRef]

17. Yan, L.; Cogan, J.D.; Hedges, L.K.; Nunley, B.; Hamid, R.; Austin, E.D. The Y Chromosome regulates BMPR2 expression via SRY: A possible reason "why" fewer males develop pulmonary arterial hypertension. Am. J. Respir. Crit. Care Med. 2018, 198, 1581-1583. [CrossRef]

18. Mathew, R. Possible mechanism/s of neointima formation in pulmonary arterial hypertension. Blood Heart Circ. 2018, 2, 1-5. [CrossRef]

19. Murakami, K.; Mathew, R.; Huang, J.; Farahami, R.; Peng, H.; Olson, S.C.; Etlinger, J.D. Smurf1 ubiquitin ligase causes downregulation of BMP receptors and is induced in monocrotaline and hypoxia models of pulmonary arterial hypertension. Exp. Biol. Med. 2010, 235, 805-813. [CrossRef]

20. McMurtry, M.S.; Moudgil, R.; Hashimoto, K.; Bonnet, S.; Michelakis, E.D.; Archer, S.L. Overexpression of human bone morphogenetic protein receptor 2 does not ameliorate monocrotaline pulmonary arterial hypertension. Am. J. Physiol. Lung Cell. Mol. Phsyiol. 2007, 292, L872-L878. [CrossRef]

21. Long, L.; Ormiston, M.L.; Yang, X.; Southwood, M.; Gräf, S.; Machado, R.D.; Moore, S.D. Selective enhancement of endothelial BMPR-II with BMP9 reverses pulmonary arterial hypertension. Nat. Med. 2015, 21,777-785. [CrossRef] [PubMed]

22. Mathew, R. Pulmonary Hypertension: Endothelial cell Function. In Pulmonary Hypertension: From Bench Research to Clinical Challenge; Sulica, R., Preston, I., Eds.; IntechOpen: London, UK, 2011; pp. 1-24. [CrossRef]

23. Li, M.; Vattulainen, S.; Aho, J.; Orcholski, M.; Rojas, V.; Yuan, K.; Koskenvuo, J.W. Loss of bone morphogenetic protein receptor 2 is associated with abnormal DNA repair in pulmonary arterial hypertension. Am. J. Respir. Cell Mol. Biol. 2014, 50, 1118-1128. [CrossRef]

24. Rothman, A.M.; Arnold, N.D.; Pickworth, J.A.; Iremonger, J.; Ciuclan, L.; Allen, R.M.; Francis, S.E. MicroRNA-140-5p and SMURF1 regulate pulmonary arterial hypertension. J. Clin. Investig. 2016, 126, 2495-2508. [CrossRef] [PubMed]

25. Mason, N.A.; Springall, D.R.; Burke, M.; Pollock, J.; Mikhail, G.; Yacoub, M.H.; Polak, J.M. High expression of endothelial nitric oxide synthase in plexiform lesions of pulmonary hypertension. J. Pathol. 1998, 185, 313-318. [CrossRef]

26. Zhao, Y.Y.; Liu, Y.; Stan, R.V.; Fan, L.; Gu, Y.; Dalton, N.; Chien, K.R. Defects in caveolin-1 cause dilated cardiomyopathy and pulmonary hypertension in knockout mice. Proc. Natl. Acad. Sci. USA 2002, 99, 11375-11380. [CrossRef] [PubMed]

27. Murata, T.; Lin, M.I.; Huang, Y.; Yu, J.; Bauer, P.M.; Giordano, F.G.; Sessa, W.C. Reexpression of caveolin-1 in endothelium rescues the vascular, cardiac, and pulmonary defects in global caveolin-1 knockout mice. J. Exp. Med. 2007, 204, 2373-2382. [CrossRef]

28. Patel, H.H.; Zhang, S.; Murray, F.; Suda, R.Y.; Head, B.P.; Yokoyama, U.; Thistlethwaite, P.A. Increased smooth muscle cell expression of caveolin-1 and caveolae contribute to the pathophysiology of idiopathic pulmonary arterial hypertension. FASEB J. 2007, 21, 2970-2979. [CrossRef]

29. Dereddy, N.; Hunag, J.; Erb, M.; Guzel, S.; Wolk, J.H.; Sett, S.S.; Mathew, R. Associated inflammation or increased flow-mediated shear stress, but not the pressure alone disrupts endothelial caveolin-1 in infants with pulmonary hypertension. Pulm. Circ. 2012, 2, 492-500. [CrossRef]

30. Huang, J.; Wolk, J.H.; Gewitz, M.H.; Loyd, J.E.; West, J.; Austin, E.D.; Mathew, R. Enhanced caveolin-1 expression in smooth muscle cells: Possible prelude to neointima formation. World J. Cardiol. 2015, 7, 671-684. [CrossRef]

31. Codrici, E.; Albulescu, L.; Popescu, I.D.; Mihai, S.; Enciu, A.M.; Albulescu, R.; Hinescu, M.E. Caveolin-1-Knockout Mouse as a Model of Inflammatory Diseases. J. Immunol. Res. 2018, 2498576. [CrossRef]

32. Jasmin, J.F.; Mercier, I.; Dupuis, J.; Tanowitz, H.B.; Lisanti, M.P. Short-term administration of a cell-permeable caveolin-1 peptide prevents the development of monocrotaline-induced pulmonary hypertension and right ventricular hypertrophy. Circulation 2006, 114, 912-920. [CrossRef] 
33. Huang, J.; Kaminski, P.M.; Edwards, J.G.; Yeh, A.; Wolin, M.S.; Frishman, W.H.; Mathew, R. Pyrrolidine dithiocarbamate restores endothelial cell membrane integrity and attenuates monocrotaline-induced pulmonary artery hypertension. Am. J. Physiol. Lung Cell. Mol. Physiol. 2008, 294, L1250-L1259. [CrossRef]

34. Bakhshi, F.R.; Mao, M.; Shajahan, A.N.; Piegeler, T.; Chen, Z.; Chernaya, O.; Comhair, S. Nitrosation-dependent caveolin 1 phosphorylation, ubiquitination, and degradation and its association with idiopathic pulmonary arterial hypertension. Pulm. Circ. 2013, 3, 816-830. [CrossRef]

35. Shiroto, T.; Romero, N.; Sugiyama, T.; Sartoretto, J.L.; Kalwa, H.; Yan, Z.; Michel, T. Caveolin-1 is a critical determinant of autophagy, metabolic switching, and oxidative stress in vascular endothelium. PLoS ONE 2014, 9, e87871. [CrossRef]

36. Huang, J.; Wolk, J.; Gewitz, M.H.; Mathew, R. Progressive Endothelial Cell Damage in an Inflammatory Model of Pulmonary Hypertension. Exp. Lung Res. 2010, 36, 57-66. [CrossRef]

37. Kravchick, D.O.; Hrdinka, M.; Iacobas, S.; Iacobas, D.A.; Kreutz, M.R.; Jordan, B.A. Synaptonuclear messenger PRR7 inhibits c-Jun ubiquitination and regulates NMDA mediated excitotoxicity. EMBO J. 2016, 35, 1923-1934. [CrossRef]

38. Iacobas, S.; Neal-Perry, G.; Iacobas, D.A. The Cytoskeleton: Imaging, Isolation, and Interaction; Springer International Publishing: New York, NY, USA, 2013; Volume 79, pp. 119-133.

39. Fan, C.; Iacobas, D.A.; Zhou, D.; Chen, Q.; Lai, J.K.; Gavrialov, O.; Haddad, G.G. Gene expression and phenotypic characterization of mouse heart after chronic constant or intermittent hypoxia. Physiol. Genom. 2005, 22, 292-307. [CrossRef]

40. Iacobas, D.A.; Iacobas, S.; Nebieridze, N.; Velisek, L.; Veliskova, J. Estrogen protects neurotransmission transcriptome during status epilepticus. Front. Neurosci. 2018, 12, 332. [CrossRef]

41. Iacobas, S.; Ede, N.; Iacobas, D.A. The Gene Master Regulators (GMR) Approach Provides Legitimate Targets for Personalized, Time-Sensitive Cancer Gene Therapy. Genes 2019, 10, 560. [CrossRef]

42. Iacobas, D.A.; Iacobas, S.; Tanowitz, H.B.; de Carvalho, A.C.; Spray, D.C. Functional genomic fabrics are remodeled in a mouse model of Chagasic cardiomyopathy and restored following cell therapy. Microbes Infect. 2018, 20, 185-195. [CrossRef]

43. Kanehisa, M.; Furumichi, M.; Tanabe, M.; Sato, Y.; Morishima, K. KEGG: New perspectives on genomes, pathways, diseases and drugs. Nucleic Acids Res. 2017, 45, D353-D361. [CrossRef]

44. Iacobas, D.A.; Chachua, T.; Iacobas, S.; Benson, M.J.; Borges, K.; Veliskova, J.; Velisek, L. ACTH and PMX53 recover the normal synaptic transcriptome in a rat model of infantile spasms. Sci. Rep. 2018, 8, 5722. [CrossRef]

45. Iacobas, D.A.; Fan, C.; Iacobas, S.; Spray, D.C.; Haddad, G.G. Transcriptomic changes in developing kidney exposed to chronic hypoxia. Biochem. Biophys. Res. Commun. 2006, 349, 329-338. [CrossRef]

46. Iacobas, D.A.; Fan, C.; Iacobas, S.; Haddad, G.G. Integrated transcriptomic responses to cardiac chronic hypoxia: Translational regulators and response to stress in cell survival. Funct. Integr. Genom. 2008, 8, 265-275. [CrossRef]

47. Iacobas, D.A.; Iacobas, S.; Haddad, G.G. Heart rhythm genomic fabric in hypoxia. Biochem. Biophys. Res. Commun. 2010, 391, 1769-1774. [CrossRef]

48. Iacobas, D.A.; Iacobas, S.; Spray, D.C. Connexin 43 and the brain transcriptome of the newborn mice. Genomics 2007, 89, 113-123. [CrossRef] [PubMed]

49. Iacobas, D.A.; Iacobas, S.; Lee, P.R.; Cohen, J.E.; Fields, R.D. Coordinated Activity of Transcriptional Networks Responding to the Pattern of Action Potential Firing in Neurons. Genes 2019, 10, 754. [CrossRef]

50. Raw and Processed Gene Expression Results were Deposited at the National Center for Biotechnology Information. Available online: https://www.ncbi.nlm.nih.gov/geo/query/acc.cgi?acc=GSE72707 (accessed on 1 December 2020).

51. Mapk3 Mitogen Activated Protein Kinase 3, National Center for Biotechnology Information. Available online: https://www.ncbi.nlm.nih.gov/gene/50689 (accessed on 1 December 2020).

52. Huang, J.; Frid, M.; Gewitz, M.H.; Fallon, J.T.; Brown, D.; Krafuser, G.; Mathew, R. Hypoxia-induced Pulmonary Hypertension and Chronic Lung Disease: Caveolin-1 Dysfunction an Important Underlying Feature. Pulm. Circ. 2019, 9, 2045894019837876. [CrossRef]

53. Huang, J.; Wolk, J.H.; Gewitz, M.H.; Mathew, R. Caveolin-1 expression during the progression of pulmonary hypertension. Exp. Biol. Med. 2012, 237, 956-965. [CrossRef] 
54. Mathew, R.; Huang, J.; Shah, M.; Patel, K.; Gewitz, M.; Sehgal, P.B. Disruption of endothelial-cell caveolin-1 $\alpha /$ raft scaffolding during development of monocrotaline-induced pulmonary hypertension. Circulation 2004, 110, 1499-1506. [CrossRef]

55. Mathew, R. Cell-specific dual role of caveolin-1 in pulmonary hypertension. Pulm. Med. 2011, $2011,573432$. [CrossRef]

56. Mathew, R. Pathogenesis of pulmonary hypertension: A case for caveolin-1 and cell membrane integrity. Am. J. Physiol. Heart Circ. Physiol. 2014, 306, H15-H25. [CrossRef]

57. Lepetit, H.; Eddahibi, S.; Fadel, E.; Frisdal, E.; Munaut, C.; Noel, A.; Lafuma, C. Smooth muscle cell matrix metalloproteinases in idiopathic pulmonary arterial hypertension. Eur. Respir. J. 2005, 25, 834-842. [CrossRef]

58. Tiede, S.L.; Wassenberg, M.; Christ, K.; Schermuly, R.T.; Seeger, W.; Grimminger, F.; Gall, H. Biomarkers of tissue remodeling predict survival in patients with pulmonary hypertension. Int. J. Cardiol. 2016, 223, 821-826. [CrossRef]

59. Dorfmüller, P.; Zarka, V.; Durand-Gasselin, I.; Monti, G.; Balabanian, K.; Garcia, G.; Emilie, D. Chemokine RANTES in severe pulmonary arterial hypertension. Am. J. Respir. Crit. Care Med. 2002, 165, 534-539. [CrossRef]

60. Nie, X.; Tan, J.; Dai, Y.; Liu, Y.; Zou, J.; Sun, J.; Bian, J.S. CCL5 deficiency rescues pulmonary vascular dysfunction, and reverses pulmonary hypertension via caveolin-1-dependent BMPR2 activation. J. Mol. Cell. Cardiol. 2018, 116, 41-56. [CrossRef]

61. Toshner, M.; Voswinckel, R.; Southwood, M.; Al-Lamki, R.; Howard, L.S.; Marchesan, D.; Stewart, S. Evidence of dysfunction of endothelial progenitors in pulmonary arterial hypertension. Am. J. Respir. Crit. Care Med. 2009, 180, 780-787. [CrossRef]

62. Zhang, T.; Kawaguchi, N.; Hayama, E.; Furutani, Y.; Nakanishi, T. High expression of CXCR4 and stem cell markers in a monocrotaline and chronic hypoxia-induced rat model of pulmonary arterial hypertension. Exp. Ther. Med. 2018, 15, 4615-4622. [CrossRef]

63. Farkas, D.; Kraskauskas, D.; Drake, J.I.; Alhussaini, A.A.; Kraskauskiene, V.; Bogaard, H.J.; Farkas, L. CXCR4 inhibition ameliorates severe obliterative pulmonary hypertension and accumulation of $\mathrm{C}-\mathrm{kit}^{+}$cells in rats. PLOS ONE 2014, 9, e89810. [CrossRef]

64. Yang, J.X.; Zhang, N.; Wang, H.W.; Gao, P.; Yang, Q.P.; Wen, Q.P. CXCR4 receptor overexpression in mesenchymal stem cells facilitates treatment of acute lung injury in rats. J. Biol. Chem. 2015, 290, 1994-2006. [CrossRef]

65. Huang, Z.; Su, G.F.; Hu, W.J.; Bi, X.X.; Zhang, L.; Wan, G. The study on expression of CIAPIN1 interfering hepatocellular carcinoma cell proliferation and its mechanisms. Eur. Rev. Med. Pharmacol. Sci. 2017, 21, 3054-3060.

66. Yang, Z.; Wang, W.E.; Zhang, Q. CIAPIN1 siRNA inhibits proliferation, migration and promotes apoptosis of VSMCs by regulating Bcl-2 and Bax. Curr. Neurovasc. Res. 2013, 10, 4-10. [CrossRef]

67. Iacobas, S.; Iacobas, D.A. Astrocyte proximity modulates the myelination gene fabric of oligodendrocytes. Neuron Glia Biol. 2010, 6, 157-169. [CrossRef]

68. Lee, P.R.; Cohen, J.E.; Iacobas, D.A.; Iacobas, S.; Fields, R.D. Gene networks activated by pattern-specific generation of action potentials in dorsal root ganglia neurons. Sci. Rep. 2017, 7, 43765. [CrossRef]

69. Clavier, L.; Legchenko, E.; Grimm, L.; Sallmon, H.; Hatch, A.; Plouff, B.D.; Hansmann, G. Galectin 3 and aldosterone as potential tandem biomarkers in pulmonary arterial hypertension. Heart 2016, 102, 390-396. [CrossRef]

70. Perretti, M.; Ingegnoli, F.; Wheller, S.K.; Blades, M.C.; Solito, E.; Pitzalis, C. Annexin 1 modulates monocyte-endothelial cell interaction in vitro and cell migration in vivo in the human SCID mouse transplantation model. J. Immunol. 2002, 169, 2085-2092. [CrossRef]

71. Drechsler, M.; de Jong, R.; Rossaint, J.; Viola, J.R.; Leoni, G.; Wang, J.M.; Döring, Y. Annexin A1 counteracts chemokine-induced arterial myeloid cell recruitment. Circ. Res. 2005, 116, 827-835. [CrossRef]

72. Sheikh, M.H.; Solito, E. Annexin A1: Uncovering the Many Talents of an Old Protein. Int. J. Mol. Sci. 2018, 19, 1045. [CrossRef]

73. De Jong, R.J.; Paulin, N.; Lemnitzer, P.; Viola, J.R.; Winter, C.; Ferraro, B.; Soehnlein, O. Protective Aptitude of Annexin A1 in Arterial Neointima Formation in Atherosclerosis-Prone Mice-Brief Report. Arterioscler. Thromb. Vasc. Biol. 2017, 37, 312-315. [CrossRef] 
74. Gore, B.; Izikki, M.; Mercier, O.; Dewachter, L.; Fadel, E.; Humbert, M.; Eddahibi, S. Key role of the endothelial TGF- $\beta / A L K 1 /$ endoglin signaling pathway in humans and rodents pulmonary hypertension. PLOS ONE 2014, 9, e100310. [CrossRef]

75. Scherer, C.; Pfisterer, L.; Wagner, A.H.; Hödebeck, M.; Cattaruzza, M.; Hecker, M.; Korff, T. Arterial wall stress controls NFAT5 activity in vascular smooth muscle cells. J. Am. Heart Assoc. 2014, 10, e000626. [CrossRef] [PubMed]

76. Cao, W.; Zhang, D.; Li, Q.; Liu, Y.; Jing, S.; Cui, J.; Yu, B. Biomechanical Stretch Induces Inflammation, Proliferation, and Migration by Activating NFAT5 in Arterial Smooth Muscle Cells. Inflammation 2017, 40, 2129-2136. [CrossRef]

77. Weiss, A.; Neubauer, M.C.; Yerabolu, D.; Kojonazarov, B.; Schlueter, B.C.; Neubert, L.; Pullamsetti, S.S. Targeting cyclin-dependent kinases for the treatment of pulmonary arterial hypertension. Nat. Commun. 2019, 10, 2204. [CrossRef]

78. Brunyanszki, A.; Szczesny, B.; Virág, L.; Szabo, C. Mitochondrial poly(ADP-ribose) polymerase: The Wizard of $\mathrm{Oz}$ at work. Free Radic. Biol. Med. 2016. [CrossRef]

79. Elser, M.; Borsig, L.; Hassa, P.O.; Erener, S.; Messner, S.; Valovka, T.; Hottiger, M.O. Poly(ADP-ribose) polymerase 1 promotes tumor cell survival by coactivating hypoxia-inducible factor-1-dependent gene expression. Mol. Cancer Res. 2008, 6, 282-290. [CrossRef]

80. Meloche, J.; Pflieger, A.; Vaillancourt, M.; Paulin, R.; Potus, F.; Zervopoulos, S.; Couture, C. Role for DNA damage signaling in pulmonary arterial hypertension. Circulation 2014, 129, 786-797. [CrossRef]

81. Park, J.B.; Nagar, H.; Choi, S.; Jung, S.B.; Kim, H.W.; Kang, S.K.; Jeon, B.H. IDH2 deficiency impairs mitochondrial function in endothelial cells and endothelium-dependent vasomotor function. Free Radic. Biol. Med. 2016, 94, 36-46. [CrossRef]

82. Lugus, J.J.; Ngoh, G.A.; Bachschmid, M.M.; Kenneth, K. Mitofusins are required for angiogenic function and modulate different signaling pathways in cultured endothelial cells. J. Mol. Cell. Cardiol. 2011, 51, 885-893. [CrossRef]

83. Chen, F.; Barman, S.; Yu, Y.; Haigh, S.; Wang, Y.; Dou, H.; Bagi, Z.; Han, W.; Su, Y.; Fu, D.J. Caveolin-1 is a negative regulator of NADPH oxidase-derived reactive oxygen species. Free Radic. Biol. Med. 2014, 73, 201-213. [CrossRef]

84. Hart, P.C.; Ratti, B.A.; Mao, M.; Ansenberger-Fricano, K.; Shajahan-Haq, A.N.; Tyner, A.L.; Bonini, M.G. Caveolin-1 regulates cancer cell metabolism via scavenging Nrf2 and suppressing MnSOD-driven glycolysis. Oncotarget 2016, 7, 308-322. [CrossRef]

85. Lu, W.; Kang, J.; Hu, K.; Tang, S.; Zhou, X.; XU, L.; Yu, S. The role of the Nox4-derived ROS-mediated RhoA/Rho kinase pathway in rat hypertension induced by chronic intermittent hypoxia. Sleep Breath. 2017, 21,667-677. [CrossRef] [PubMed]

86. Gräf, S.; Haimel, M.; Bleda, M.; Hadinnapola, C.; Southgate, L.; Li, W.; Machado, R.D. Identification of rare sequence variation underlying heritable pulmonary arterial hypertension. Nat. Commun. 2018, 9, 1416. [CrossRef] [PubMed]

87. Oka, M.; Fagan, K.A.; Jones, P.L.; McMurtry, I.F. Therapeutic potential of RhoA/Rho kinase inhibitors in pulmonary hypertension. Br. J. Pharmacol. 2008, 155, 444-454. [CrossRef] [PubMed]

(C) 2020 by the authors. Licensee MDPI, Basel, Switzerland. This article is an open access article distributed under the terms and conditions of the Creative Commons Attribution (CC BY) license (http://creativecommons.org/licenses/by/4.0/). 